\title{
DOE Hydropower Program Annual Report for FY 2002
}

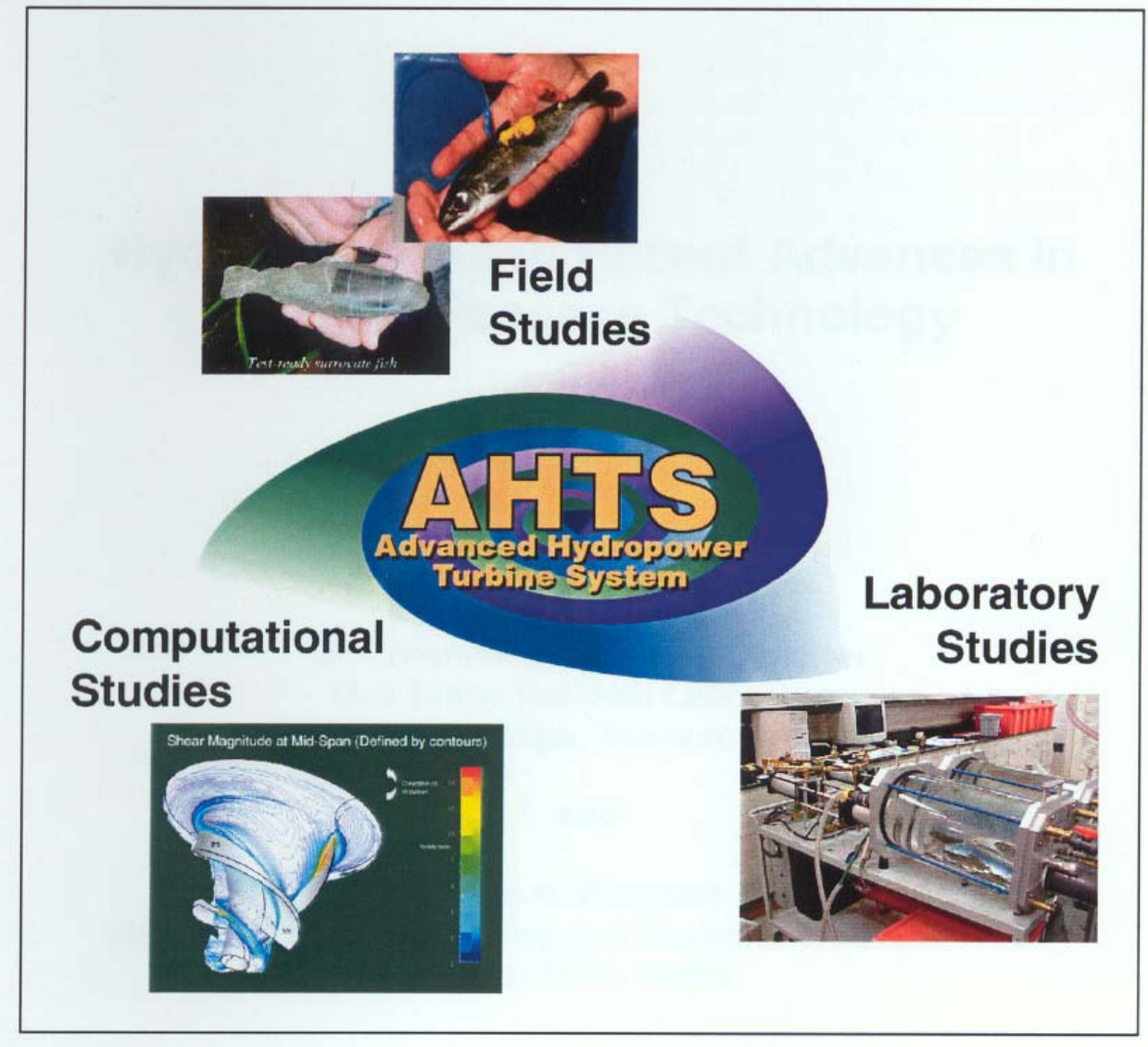

\section{U.S. Department of Energy}

Energy Efficiency and Renewable Energy

Wind and Hydropower Technologies 



\title{
DOE Hydropower Program Annual Report for FY 2002
}

(October 2001 - September 2002)

\author{
M. J. Sale ${ }^{1}$ \\ G. F. Cada ${ }^{1}$ \\ T. J. Carlson ${ }^{2}$ \\ D. D. Dauble ${ }^{2}$ \\ R. T. Hunt ${ }^{3}$ \\ G. L. Sommers ${ }^{3}$
}

July 2003

Prepared for the

U.S. Department of Energy

Office of Energy Efficiency and Renewable Energy

Wind and Hydropower Technologies

1 Oak Ridge National Laboratory

2 Pacific Northwest National Laboratory

${ }^{3}$ Idaho National Engineering and Environmental Laboratory 



\section{SUMMARY}

The U.S. Department of Energy (DOE) conducts research on advanced hydropower technology through its hydropower program, which is organized under the Office of Wind and Hydropower Technologies within the Office of Energy Efficiency and Renewable Energy. This annual report describes the various projects supported by the hydropower program in FY 2002. The program's current focus is on improving the environmental performance of hydropower projects by addressing problems such as fish mortality during passage through turbines, alteration of instream habitat, and water quality in tailwaters. A primary goal of this research is to develop new, environmentally friendly technology. DOE-funded projects have produced new conceptual designs for turbine systems, and these are now being tested in pilot-scale laboratory tests and in the field. New design approaches range from totally new turbine runners to modifications of existing designs. Biological design criteria for these new turbines have also been developed in controlled laboratory tests of fish response to physical stresses, such as hydraulic shear and pressure changes. These biocriteria are being combined with computational tools to locate and eliminate areas inside turbine systems that are damaging to fish. Through the combination of laboratory, field, and computational studies, new solutions are being found to environmental problems at hydropower projects. The diverse program activities continue to make unique contributions to clean energy production in the U.S. By working toward technology improvements that can reduce environmental problems, the program is helping to reposition hydropower as an acceptable, renewable, domestic energy choice.

The key successes in FY 2002 were:

- Biological and engineering tests at the pilot-scale test facility at Alden Research Laboratory, to evaluate the environmental and engineering performance of the new Alden/Concepts NREC runner (Hecker et al. 2002).

- Publication of new biological response studies of the effects of pressure and dissolved gas supersaturation on fish passing through hydropower turbines (Abernethy et al. 2001, 2002).

- Deployment of the phase II sensor fish device at Columbia River dams to evaluate hydraulic forces present in spillways and a high-volume outfall.

- Collaboration with industry and other federal agencies in two successful workshops to identify future R\&D needs for hydropower.

- Establishment of financial assistance agreements for field testing of large turbines (Box Canyon Project, Osage Project, and Wanapum Project).

- Development of a methodology for low head/low power hydropower resource assessment and completion of two hydrologic regions. 


\section{CONTENTS}

SUMMARY iii

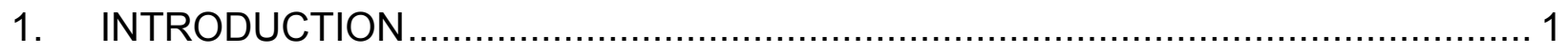

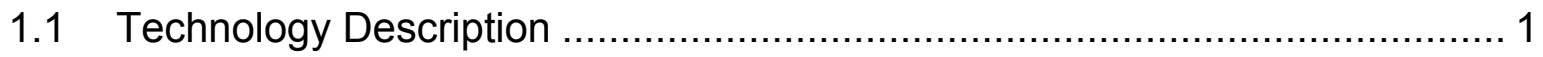

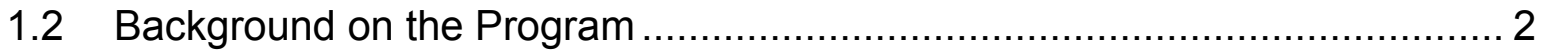

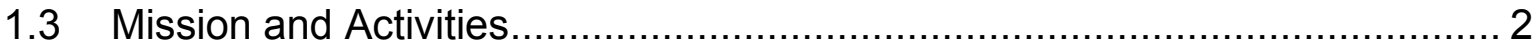

1.4 Program Organization and Management ............................................. 3

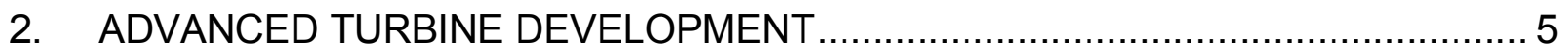

2.1 Pilot-Scale Testing of the Alden Concepts/NREC Runner ........................... 6

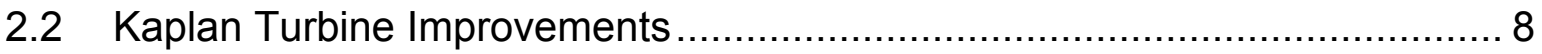

2.3 Field Testing of Large Turbines ....................................................... 9

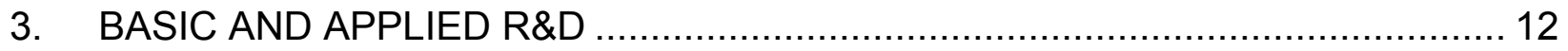

3.1 Laboratory Studies of Fish Response to Turbine Passage Stresses ........... 12

3.2 Draft Tube and Tailrace Studies ............................................................ 16

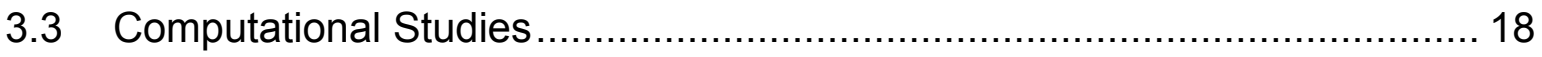

3.4 Instrumentation and Monitoring Technology ……................................... 21

4. ENVIRONMENTAL MITIGATION AND OTHER STUDIES ................................ 25

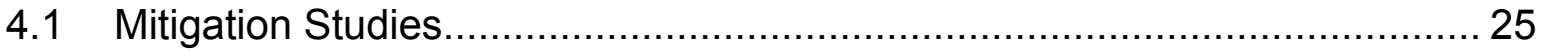

4.2 Other Studies of Impacts to Fish...................................................... 26

5. LOW HEAD/LOW POWER HYDROPOWER TECHNOLOGY ........................... 28

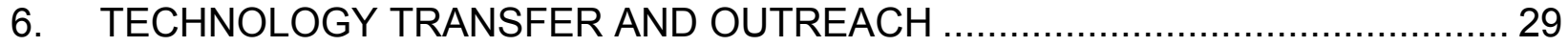

6.1 Interagency Coordination and Outreach .............................................. 29

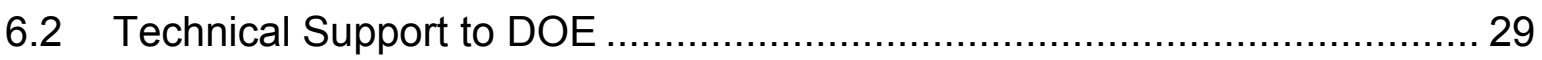

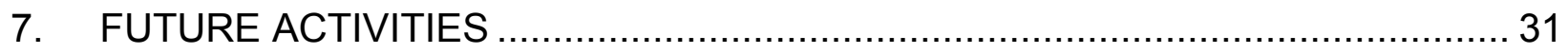




\section{CONTENTS (continued)}

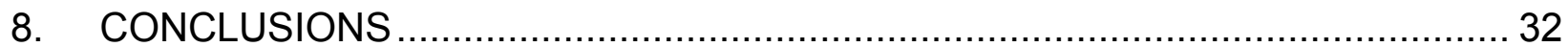

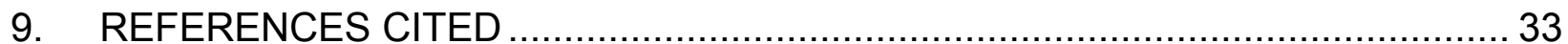

Appendix A—Renewable Indian Energy Resources Program.................................. 38

FIGURES

1. Components of the DOE hydropower program in FY 2002 .............................

2. Sources of injury to fish passing through hydropower turbines ...........................

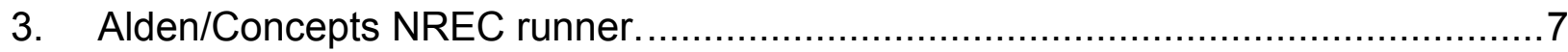

4. Test loop at Alden Research Laboratory, Holden, Massachusetts..........................7

5. Sites for field testing of large turbines. From top to bottom, the photos depict the Wampum, Osage, and Box Canyon projects. ..............................................11

6. Examples of tissue damage to fish during turbine passage ................................14

7. C-shaped swimming movement used to escape predators. ...............................15

8. The use of Acoustic Doppler Velocimeters (ADVs) to measure turbulence in the draft tube of Melton Hill Dam, Tennessee...............................................18

9. Damaging shear zones in Kaplan turbines. From Garrison et al. (2002)..............19

10. Reverse direction and recirculating particle trajectories in a simulation of water flow through the draft tube at Norris Dam............................................20

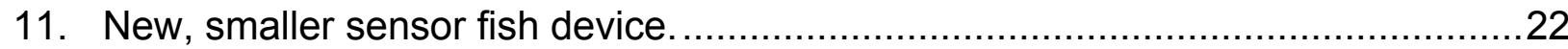

12. Pressure sensitive films wrapped around a sensor fish that passed down the Bonneville Dam spillway on August 28, 2002. Pressures registered by the films ranged from 360 psi (black areas) to 7700 psi (red spot).

13. Green Cyalume chemical light sticks (2", 4", and 1.5" from left to right) used in feasibility testing at Bonneville and McNary Dams and in evaluation of camera tracking arrays.

14. Steelhead smolt tagged with a light tag 



\section{DOE Hydropower Program Annual Report for FY 2002}

\section{INTRODUCTION}

This report describes hydropower activities supported by the U.S. Department of Energy (DOE) Wind and Hydropower Program during Fiscal Year 2002 (October 1, 2001 to September 30, 2002). Background on the program, current activities, and future plans are presented in the following sections.

\subsection{Technology Description}

Hydropower is one of the nation's most important renewable energy resources, because it represents about $7-10 \%$ of the country's electrical generating capability and provides more than $75 \%$ of the electricity generated from renewable sources.

Technology for producing hydroelectricity from falling water has existed for more than a century. Hydropower has significant advantages over other energy sources: it is a reliable, domestic, renewable resource with large undeveloped potential, and it emits essentially none of the atmospheric emissions that are of growing concern, such as nitrogen and sulfur oxides and greenhouse gases. Hydropower projects can provide substantial nonpower benefits as well, including water supply, flood control, navigation, and recreation.

Hydropower poses unique challenges in energy development, because it combines great benefits with some difficult environmental challenges. The benefits of hydropower can sometimes be offset by adverse environmental impacts (e.g., Mattice, 1991). The environmental issues that most frequently confront the hydropower industry are blockage of upstream fish passage, fish injury and mortality from passage through turbines, and changes in the quality and quantity of water released below dams and diversions.

The current installed capacity of hydropower in the U.S. is approximately 78,000 MW (EIA 2002). Hydroelectricity is produced at about 180 federal projects and more than 2,000 non-federal projects that are regulated by the Federal Energy Regulatory Commission (FERC) in all 50 states and Puerto Rico. Although there are substantial undeveloped resources in the U.S. (Conner et al. 1998), hydropower's share of the nation's generation is predicted to decline through 2020 to about $6 \%$, due to a combination of environmental issues, regulatory complexity and pressures, and changes in energy economics. Almost no new hydropower capacity is predicted through 2020 (EIA 2002). 


\subsection{Background on the Program}

DOE has been supporting hydropower R\&D for 25 years, beginning with a LowHead Hydropower Feasibility Program that was initiated in 1978. More recently, the program has conducted research on environmental mitigation practices. These studies provided greater understanding of environmental problems, and the benefits and costs of potential solutions. The first report on this subject considered mitigation for problems associated with fish passage, dissolved oxygen, and instream flows (Sale et al. 1991). The second report provided a detailed examination of the benefits and costs of upstream and downstream fish passage measures at 16 hydroelectric projects (Francfort et al. 1994). Since 1994, a major emphasis of the program has been the development of advanced, environmentally friendly turbines (see Section 2). In addition, the hydropower program has performed hydropower resource assessments, engaged in cost-shared research with industry, and promoted technology transfer. For example, DOE established a multi-agency team to quantify potential, undeveloped hydropower resources in the U.S. A preliminary resource assessment was completed in 1990, and the analyses have been refined and updated since then (Conner et al. 1998). The program's contributions have been summarized in regular biennial and annual reports (e.g., Sale et al. 2001). Annual and topical research reports are available on the DOE hydropower technologies web site: http:// www.eere.energy.gov/.

\subsection{Mission and Activities}

The mission of the DOE's hydropower program is to conduct research and development (R\&D) to improve the technical, societal, and environmental benefits of hydropower. The program seeks to develop advanced hydropower technologies that will improve hydropower's environmental performance, and thereby allow it to co-exist with other water resource uses and remain a significant contributor to the nation's energy portfolio. The program currently supports research and other activities in six areas (Figure 1):

- Development of advanced hydropower turbines with enhanced environmental performance;

- Basic and applied research that supports and enables the development of new hydropower technology;

- Studies of environmental mitigation and other issues that affect hydropower development;

- Development of unconventional hydroelectric generating technologies, such as lowhead/low-power equipment (including microhydro), that can be implemented for distributed energy production;

- Technology transfer and coordination with other agencies and industry; and

- Administration of hydropower and related projects in the Renewable Indian Energy Resources Program in Alaska. 


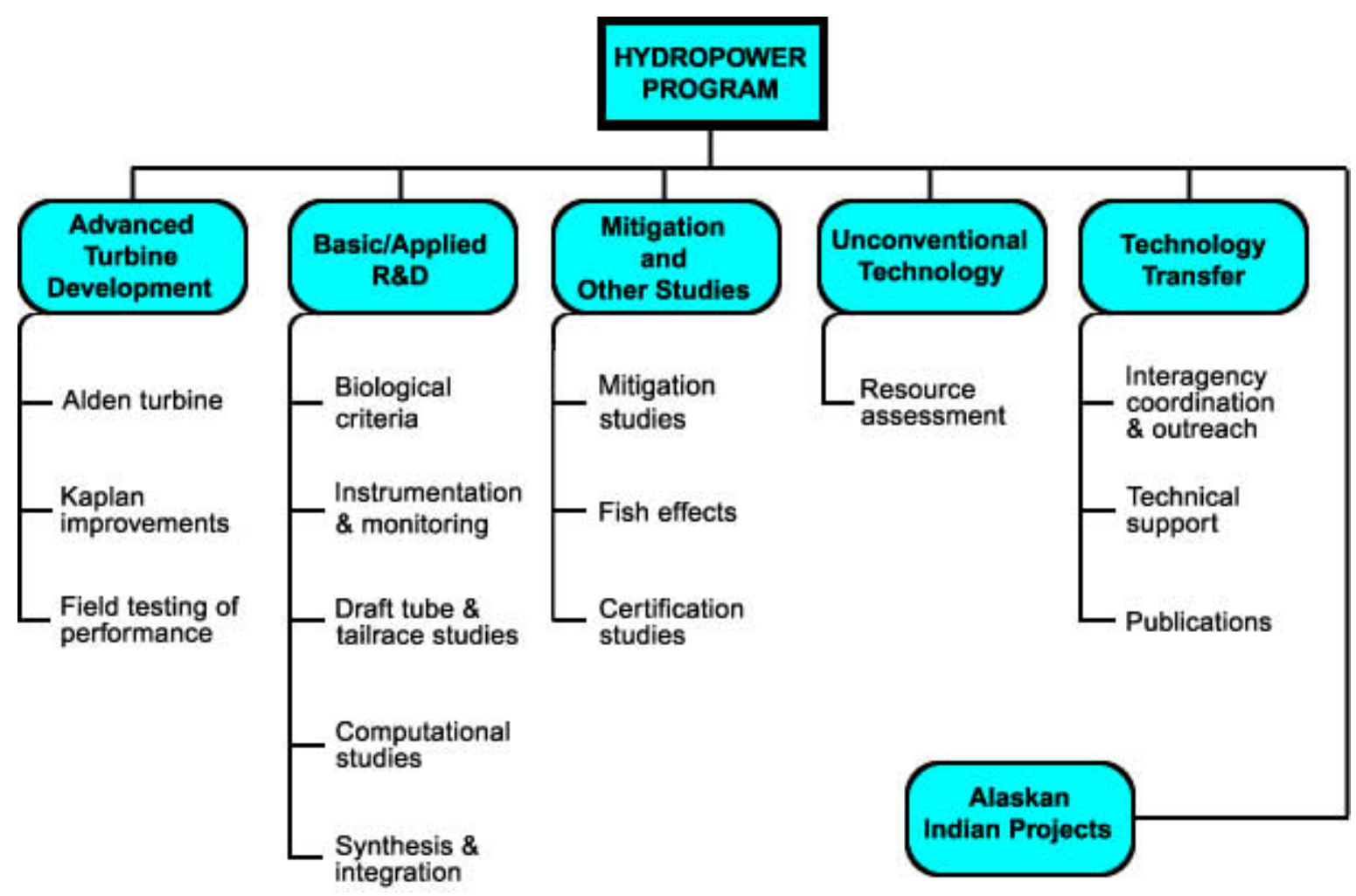

Figure 1. Components of the DOE hydropower program in FY 2002.

Program activities focus on applied R\&D, managed by Federal personnel and performed by national laboratories and industry partners. Whenever possible, costsharing and other types of cooperation are used to leverage DOE funding. The program uses a multi-faceted research approach, combining engineering design and construction, field, laboratory, and computational studies.

\subsection{Program Organization and Management}

The hydropower program is organized under the DOE Office of Wind and Hydropower Technologies, Office of Energy Efficiency and Renewable Energy, in Washington, DC. A concerted effort is made to coordinate DOE's research and development with that of other federal agencies and industry, including both private and public entities involved with hydropower development. An open peer-review process involving industry and environmental resource agencies ensures that stakeholders are involved and that high-priority research needs are being addressed (see Section 6). A Technical Committee is maintained to review progress, evaluate results, and ensure coordination with related R\&D activities of other agencies and industry. This Technical committee consists of experts from the hydropower industry and state and Federal agencies. In addition, the reviews of specialists who are not members of the Technical 
Committee are obtained, when appropriate. Active coordination provides "situational awareness," avoids duplication of research efforts, and creates a synergy among related research effects.

Three of DOE's National Laboratories with experience in hydropower issues provide technical support to the Program: Idaho National Engineering and Environmental Laboratory (INEEL), Oak Ridge National Laboratory (ORNL), and Pacific Northwest National Laboratory (PNNL). The laboratory for engineering and program management support is INEEL. ORNL is the laboratory for environmental and computational support. PNNL provides biological and other studies, taking advantage of their experience and facilities for conducting tests on fish. A combination of industry, universities, and federal facilities conduct research activities for the hydropower program. Where federal facilities have the equipment and personnel to reduce the overall cost to DOE, they are used for conducting R\&D. 


\section{ADVANCED TURBINE DEVELOPMENT}

The goal of DOE's Advanced Hydropower Turbine Systems (AHTS) research is to improve the overall performance and acceptability of hydropower projects by developing and testing advanced turbine technologies that reduce or eliminate adverse environmental effects. Environmental problems with the highest priority include: 1) injury and mortality to fish as they pass through turbines (Figure 2), 2) degraded water quality downstream of the dams, and 3 ) altered stream flows and associated habitat for aquatic organisms (Sale et al. 1991; HCl 1992). For most of the past decade, the hydropower "system" that the DOE program concentrated on was defined as the area between the forebay of turbine inflows and the exit of the turbine's draft tube (Brookshier et al. 1995). These system boundaries are being expanded, as funding appropriations allow. The Program's research on turbulence in draft tubes and tailraces that was initiated in FY 2001 (Section 3.2) is one example of expanding the boundaries of the turbine systems being studied.

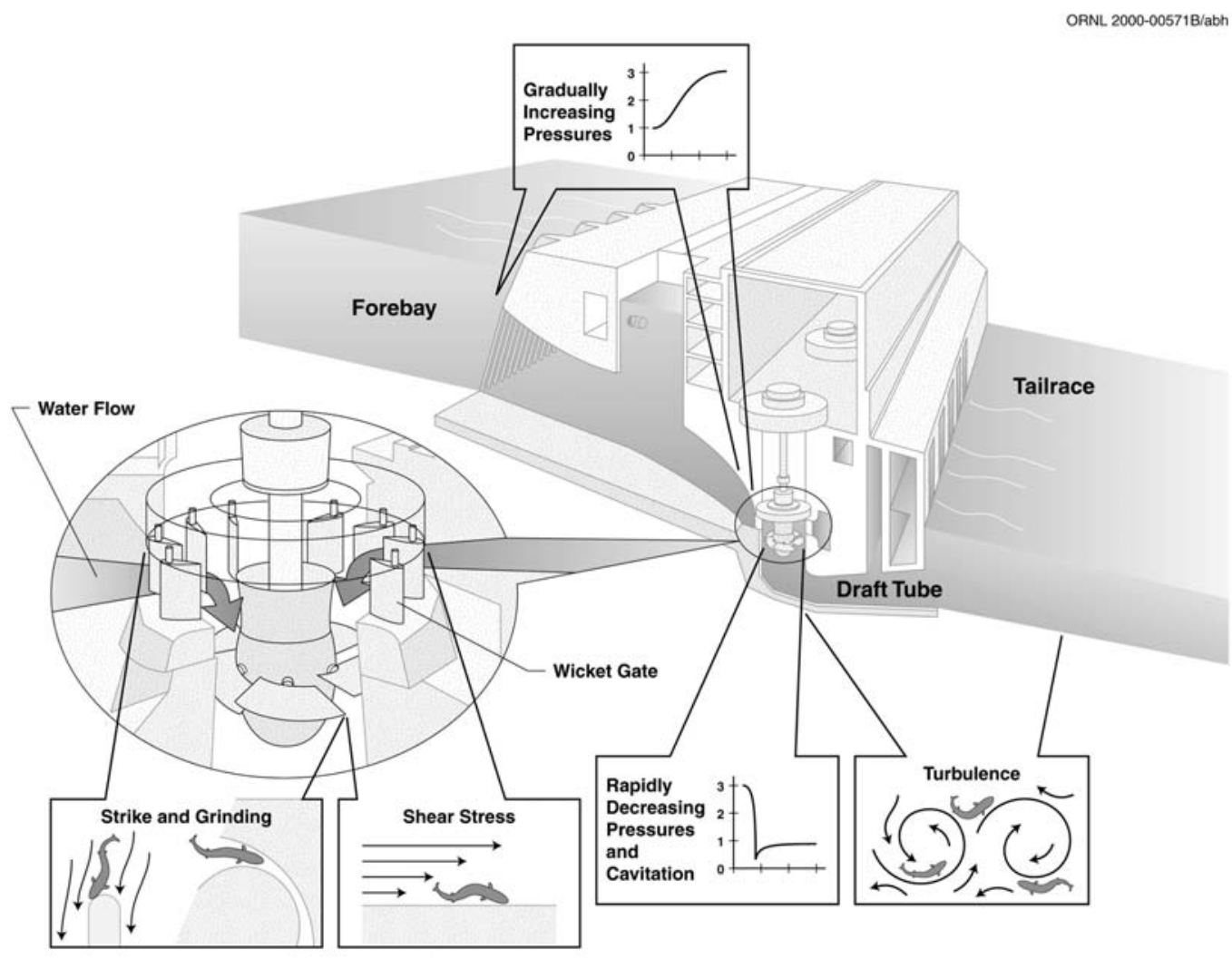

Figure 2. Sources of injury to fish passing through hydropower turbines (Cada et al. 1997).

The AHTS initiative began in February 1993, when DOE, EPRI, and the Research and Development Committee of the National Hydropower Association (NHA) met to discuss new research initiatives (Sale et al. 2000). Shortly thereafter, NHA 
formed a non-profit organization called the Hydropower Research Foundation, Inc. (HRF) to support this kind of research. Later in 1993, NHA and HRF obtained financial contributions from nine utility members and from EPRI totaling $\$ 500,000$ to support joint research on advanced turbines. DOE matched these industry contributions, creating a $\$ 1$ million fund to support the first phase of advanced turbine development. With this funding, competitive awards were made to Alden Research Laboratory, Inc. (Alden) and its partner, Northern Research and Engineering Corporation (Concepts NREC), and to Voith Hydro, Inc. (Voith; now Voith Siemens Hydro Power Generation) in October 1995. Conceptual design reports were completed by both Alden/Concepts NREC (Cook et al. 1997) and Voith (Franke et al. 1997); these were summarized by Odeh (1999).

In FY 2002, four areas of research on advanced turbines included: 1) proof-ofconcept, pilot-scale testing of the new turbine runner designed by Alden/Concepts NREC (Section 2.1), 2) field tests of advanced designs of conventional Kaplan turbines (Section 2.2), 3) a solicitation for new, cost-shared projects to verify environmental performance of new technology at full-scale, field sites (Section 2.3), and 4) field and computer modeling studies of the turbulence in draft tubes and tailraces, (Section 3.2). In many of these areas, multiple projects were supported to study both new and existing turbine designs, taking advantage of interagency cooperation and cost-sharing where possible. Different research approaches are being applied among these projects to develop better understanding of the physical stresses experienced by fish as they travel along different paths through turbines. Each of these complements the others when results are integrated.

\subsection{Pilot-Scale Testing of the Alden Concepts/NREC Runner}

In the initial phase of the AHTS research, the Alden/NREC team developed a conceptual design for a new turbine runner that would minimize both the sources of injury to fish and the penalty on turbine efficiency (Cook et al. 1997; Hecker et al. 1997). The new runner, which is based on the shape of a pump impeller (Figure 3), minimizes the number of blade leading edges, reduces the pressure versus time and the velocity versus distance gradients within the runner, minimizes clearance between the runner and runner housing, and maximizes the size of flow passages, all with minimal penalty on turbine efficiency. The flow characteristics of the new runner were analyzed using two-dimensional and three-dimensional Computational Fluid Dynamics (CFD) models.

Due to the uniqueness of this new runner and the biological assumptions with which it was designed, DOE decided to build a prototype model and facility where it could be tested (Cook et al. 2000). Construction of the test facility at Alden Research Laboratory (ARL) in Holden, Massachusetts, was completed in FY 2001, and testing operations began in September 2001. The test facility is centered on a 1/3-scale, 3.5-foot diameter prototype runner set in a closed-loop system that is large enough to pass fish (Figure 4). Injection ports for control fish (not subject to turbine passage) are built into the test loop, along with a fish screen and recovery chamber. The first phase of 
biological and hydraulic testing was completed in October 2001. The report of the Fall 2001 engineering and biological tests was issued March 2002. Review of the Fall 2001 tests resulted in several revisions to the planned Spring 2002 and Fall 2002 tests.

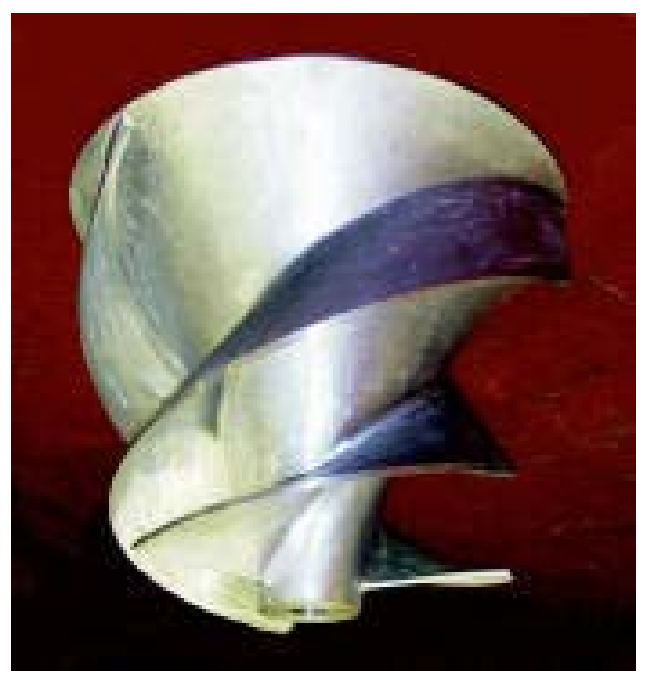

Figure 3. Alden/Concepts NREC runner.

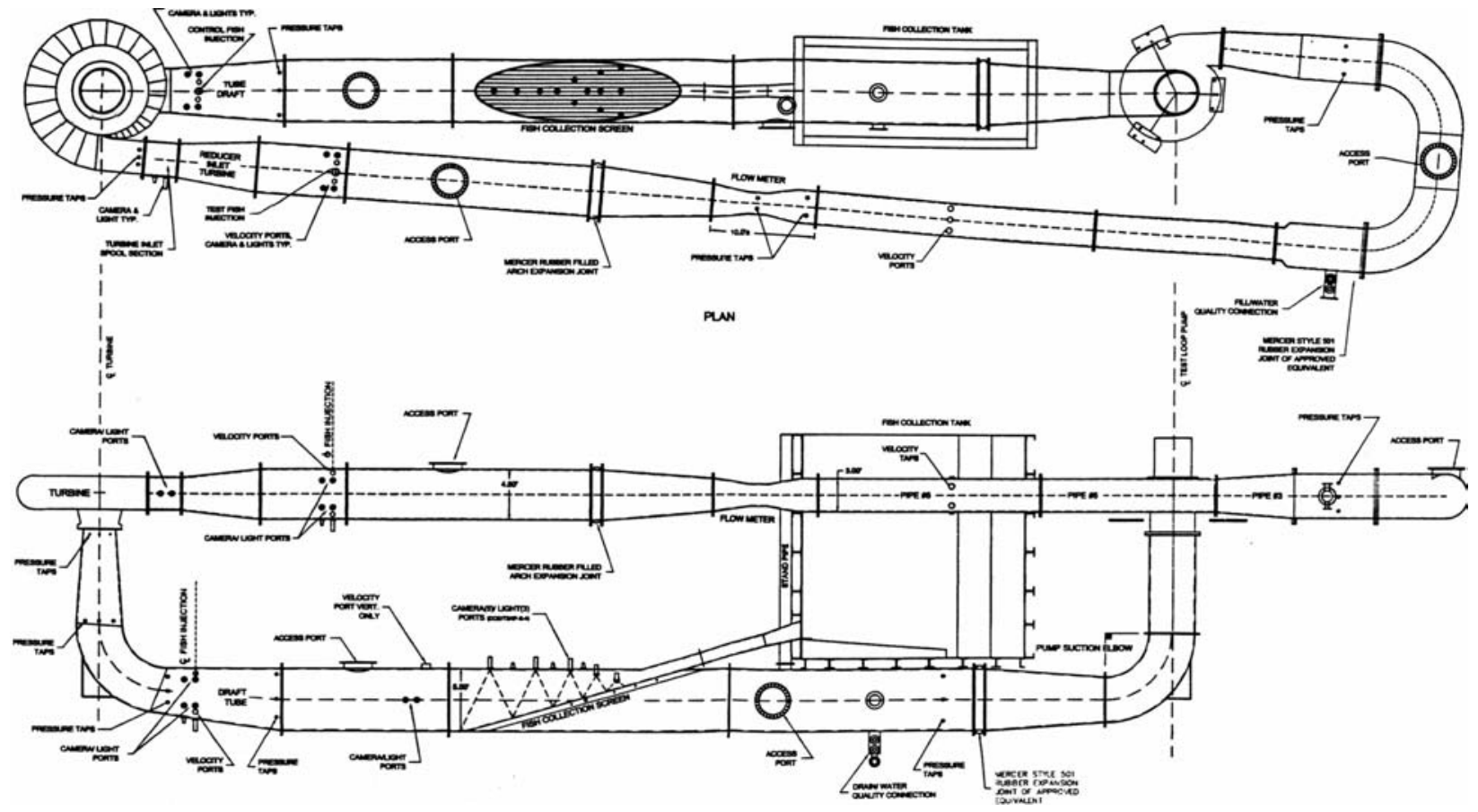

Figure 4. Test loop at Alden Research Laboratory, Holden, Massachusetts. 
The Spring tests began in April 2002 and were completed in early June 2002. The report for the Spring 2002 tests was issued in July 2002. The Fall 2002 tests began in September. During the spring and fall tests several visits to Alden were conducted by various members of the technical committee to review both the biological and engineering tests.

\subsection{Kaplan Turbine Improvements}

DOE supports several studies to improve the environmental performance of more traditional turbine designs, particularly Kaplan turbines. This research direction is a direct product of the AHTS conceptual design work by the Voith team (Franke et al. 1997, Odeh 1999). Much of this work is cost-shared with the U.S. Army Corps of Engineers (Corps) or private industry, as indicated below.

Stay vane and wicket gate studies. This a jointly funded project between the Corps of Engineers' Hydroelectric Design Center and DOE, examining the relationship between turbine wicket gate and stay vane positions to improve both safe fish passage and unit performance. The work is being performed by the U.S. Army Engineering Research and Development Center (ERDC) in Vicksburg, Mississippi and VA Tech in Austria. Research results will be incorporated into an existing model of the Lower Granite Project (lower Snake River) turbine, and flow patterns will be studied using neutrally buoyant beads passing through the turbine. The project consists of the following tasks:

- Prepare a 3-D flow net model of the Lower Granite turbine intake and scroll case;

- Perform a CFD analysis of the existing configuration and develop a structurally feasible alternative design to improve overall model efficiency;

- Select a design for model testing;

- Conduct model tests with and without fish screens to evaluate bead paths for both installations;

- Conduct model tests with modifications to stay vanes and wicket gates; and

- Prepare a report on study results.

In FY 2002 modifications of stay vanes and wicket gates were tested in the Lower Granite runner models at ERDC. These modifications can be completed in the field with minimal construction. Improvements in performance ranged up to $0.75 \%$. The report presenting all study results will be delivered in FY 2003.

Bonneville Turbine Model. This project is another jointly funded study being conducted at ERDC. The project involves these tasks:

- Fabricating two 1:25 scale Kaplan turbine models (a standard runner and an advanced minimum gap runner or MGR); 
- Constructing a 1:25 scale model of a Bonneville Powerhouse \#1 turbine bay that includes three flow bays, scroll case, wicket gates, stay vanes, draft tube, trashracks, vertical barrier screens, 600 feet of upstream approach topography, and 300 feet of downstream topography; and

- Installing and conducting experiments on these turbine models to identify fish passage routes through the turbines for three predetermined fish release points.

In FY 2002 all bead testing of both the standard runner and minimum gap runner (MGR) models were completed at the ERDC. All data was collected and compiled for both runners. Delivery of the report is scheduled for FY 2003.

McNary Turbine Fish Survival Tests. In a third project jointly funded by DOE and the Corps, fish passage studies are being conducted at McNary Dam on the Columbia River to determine the survival rates of fish passing through Kaplan turbines. In the first year of tests, fish were released at four different locations within the turbine: near the turbine hub, near the blade tip, near the middle of the blade, and near a wicket gate. The tests were conducted at a single operating condition within one percent of the peak operating efficiency at that turbine setting. No control releases of fish were conducted. Therefore, absolute survival rates could not be estimated, but the relative survival associated with each of the passage routes was determined.

In FY 2002 final release of fish through the turbines was completed. As part of these tests, direct scale damage was also monitored in the gate well. Of the four flows tested, total survival was slightly higher for the $14,400 \mathrm{cfs}$ condition (maximum turbine flow is $16,400 \mathrm{cfs}$ ). Additional consulting work to be contracted for McNary includes verification of the CFD models developed for the analysis. The report presenting all study results will be delivered in FY 2003.

\subsection{Field Testing of Large Turbines}

To stimulate the evaluation of more environmentally friendly technology, DOE partially funded field testing of turbine designs that have been developed outside the DOE program. This effort has identified advanced turbine designs other than the first two AHTS concepts and will address other environmental issues confronting the hydropower industry beyond fish passage. These tests will be conducted at full-scale, operating hydropower plants, in part because biological processes of interest are difficult to scale up from the laboratory setting. The tests will determine environmental and engineering performance and estimate the incremental O\&M costs of new designs relative to existing technology.

A Notice of Intent for this field-testing initiative was issued by DOE, seeking comments on testing new design concepts for larger turbines (>1 MW). Based on the comments received, solicitations for large-scale field testing were made in two phases: the first phase selected the conceptual turbine designs to be tested and the second 
phase selected the site development teams and the location where new equipment will be installed. The first phase was completed in January 2002. A meeting was held with the selected contractors to develop specification requirements for the second phase. The second solicitation was issued March 2002. The proposals were received, evaluated and the concepts selected in June 2002. The financial assistance agreements were awarded in September 2002.

The three project operators selected to cost share the field tests were AmerenUE and Grant County and Pend Oreille County Public Utility districts (Figure 5):

- AmerenUE, headquartered in St. Louis, has proposed testing a retrofit aeration system, built by American Hydro Corp., at its 176.2-MW Osage Project on Missouri's Lake of the Ozarks. The system is to increase the amount of dissolved oxygen downstream of the turbine to improve water quality and fisheries habitat.

- Grant County PUD of Ephrata, Washington, has proposed testing a minimum gap Kaplan turbine runner built by Voith Siemens Hydro Power Generation at Wanapum Dam on the Columbia River, part of the 1,755-MW Priest Rapids Project. The system is designed to help salmon smolts pass through the turbine without injury as they migrate downstream to the Pacific Ocean.

- Pend Oreille County PUD of Newport, Washington, has proposed testing two advanced turbines at its 72-MW Box Canyon Project on the Pend Oreille River; a minimum gap Kaplan runner built by Alstom Power, Inc. and a minimum gap Kaplan runner by Voith Siemens Hydro Power Generation. Both systems are designed to pass resident fish, such as bull trout. 

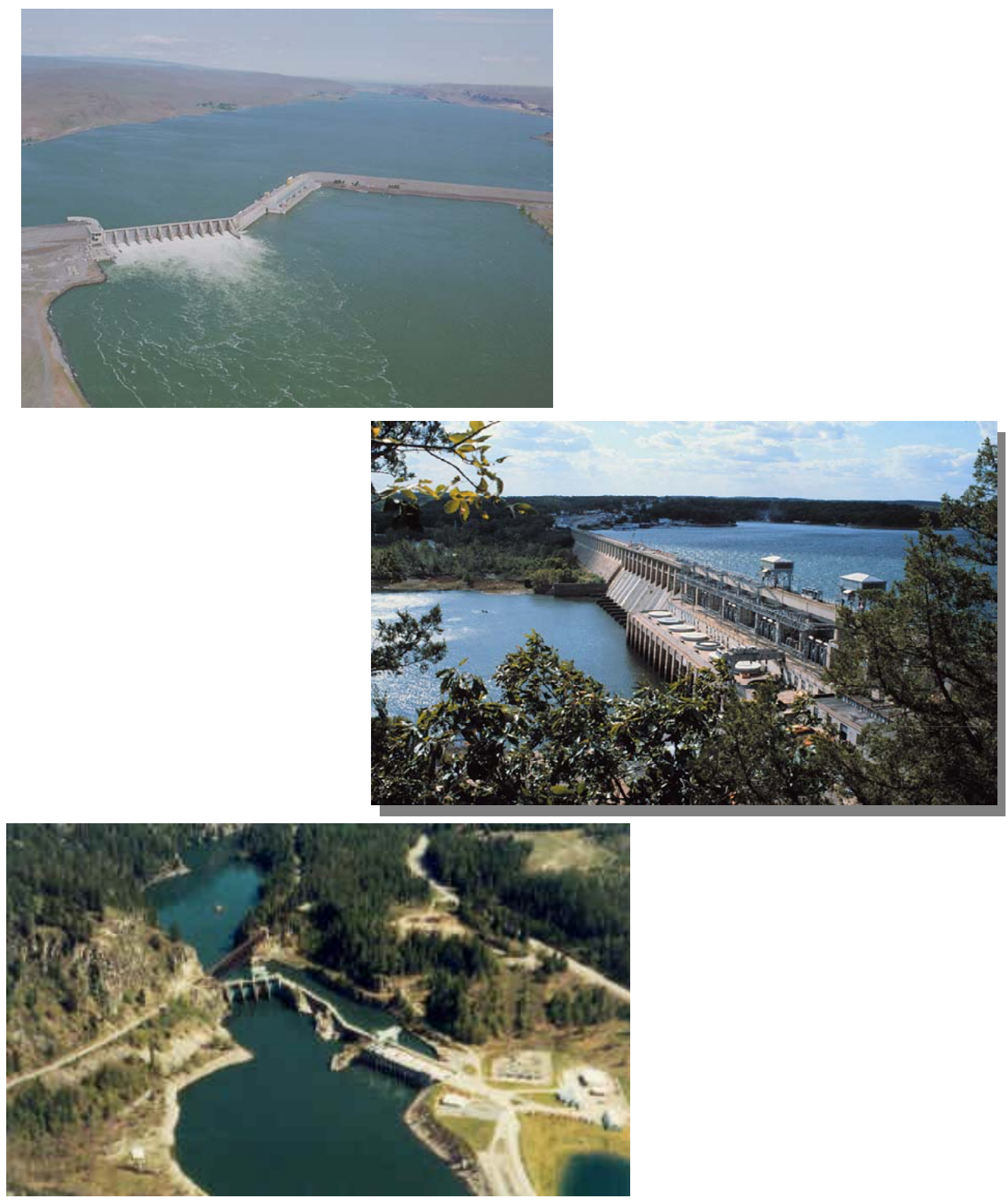

Figure 5. Sites for field testing of large turbines. From top to bottom, the photos depict the Wampum, Osage, and Box Canyon projects. 


\section{BASIC AND APPLIED R\&D}

The DOE hydropower program supports several research projects that contribute to its goal of improving the environmental performance of hydropower technology. Most of these promote the development of advanced turbines by producing new understanding of the stresses that kill or injure fish or by developing new tools that can be applied in turbine design.

In FY 2002, three complementary efforts were carried out to understand effects of physical stresses on turbine-passed fish: 1) laboratory studies of the biological response of fish to the physical stresses experienced in passage through turbines; 2) development of new instruments and monitoring technology to measure the physical conditions inside turbines in the field, and 3) application of advanced computational techniques to describe the full range of hydraulic environments in turbines under different operating conditions. All three components are needed to develop a better understanding of the adverse effects of turbine passage and the modifications needed to reduce those effects (Cada et al. 2001). Integration of results from these types of studies can improve the accuracy of predictive models and, in the future, may reduce the need for live fish in the testing of hydroelectric turbines.

\subsection{Laboratory Studies of Fish Response to Turbine Passage Stresses}

As conceptual designs for advanced turbines were developed in earlier phases of the program, it became clear that there were significant gaps in the understanding of how fish respond to physical stresses experienced during turbine passage. Although the potential injury mechanisms affecting turbine-passed fish were first described for the hydropower program in the 1990s (e.g., Cada 1990; Cada et al. 1997), many of these biological effects remain poorly understood (Cada 1998). Consequently, the AHTS Technical Committee recommended that the R\&D activities of the Program be broadened to include laboratory studies that could be used to develop biological design criteria (biocriteria) for turbines. The specific biocriteria issues examined in FY 2002 were the effects of pressure changes and dissolved gas supersaturation.

Effects of Pressure During Turbine Passage. Pressure change inside turbines is one of many potential sources of injury and mortality for fish during turbine passage (Cada et al. 1997). In FY2000, studies were completed where fish were subjected to pressure regimes expected during passage through a typical Kaplan turbine used at most dams on the Columbia River (Abernethy et al. 2001). In FY2001, fish were subjected to a modified Kaplan turbine pressure regime with a less-severe pressure change to evaluate the contribution of the pressure decrease on fish injury and mortality (Abernethy et al. 2002). Another series of laboratory tests simulating fish passage through a horizontal bulb turbine continued into FY2002. 
Two milestones were reached in FY2002. First, the final set of laboratory tests involving fish subjected to pressure conditions simulating passage through a horizontal bulb turbine was completed. Pressure conditions for these tests were modeled on pressure conditions predicted for a bulb turbine facility in Racine, Ohio. Additionally, a technical report detailing the results of these tests was published (Abernethy et al. 2002).

Quantification of Hydraulic Forces. Laboratory studies by Neitzel et al. (2000a) showed that fish can be injured or killed by hydraulic forces known to be present in hydroelectric turbines. Biological criteria, based on strain rates, were developed for exposures to shear and provided an index of injury/mortality for juvenile salmonids and American shad. However, there has been no research to verify specific injury mechanisms and threshold values for hydraulic forces that fish may experience during turbine passage. To address this issue, a sophisticated analysis of video records obtained during the Neitzel et al. (2000b) studies was conducted. The path or exposure trajectory of each fish during release into the shear environment was digitized from video records and dynamic parameters such as acceleration, jerk, and force were then computed. Analysis of the fish release/video data (Figure 6) showed that operculum injuries occurred at even the lowest levels of fluid shear applied to fish by Neitzel et al. (2000b). Smaller fish were more resistant to visible physical injury, but more susceptible to disorientation. Fish having less mass and inertia sustained smaller forces overall, but experienced more severe inertial stresses from higher levels of acceleration and jerk. Acceleration, jerk and force were all correlated with injury, with force being the most powerful predictor of visible physical injuries. A test protocol for mechanical tests that would allow threshold forces and stresses, and the biomechanical properties of certain fish organs to be measured directly was also developed. A number of mechanical tests were developed from this research that could help resolve the forces and stresses required to cause the most common observed injuries such as opercle tearing, eye loss and bruising. Development of the biomechanical test protocols showed that laboratory tests will be difficult to extrapolate to the fluid environment given our present ability to quantify such complex fluid/solid interaction. The next phase will be to integrate the results of these laboratory tests with CFD modeling.

Indirect Mortality. Fish may not be killed directly from passage through a hydroelectric turbine, but may nonetheless experience sublethal stresses (e.g., disorienting turbulence) that will increase their susceptibility to predators (indirect mortality). Modifications in the design of turbines or bypasses can be evaluated for success in reducing direct mortality, but the importance of indirect mortality is not evaluated as easily. ORNL is developing a test for indirect mortality as a means to more fully assess the consequences of passage through turbines (and other routes around a hydroelectric dam). 

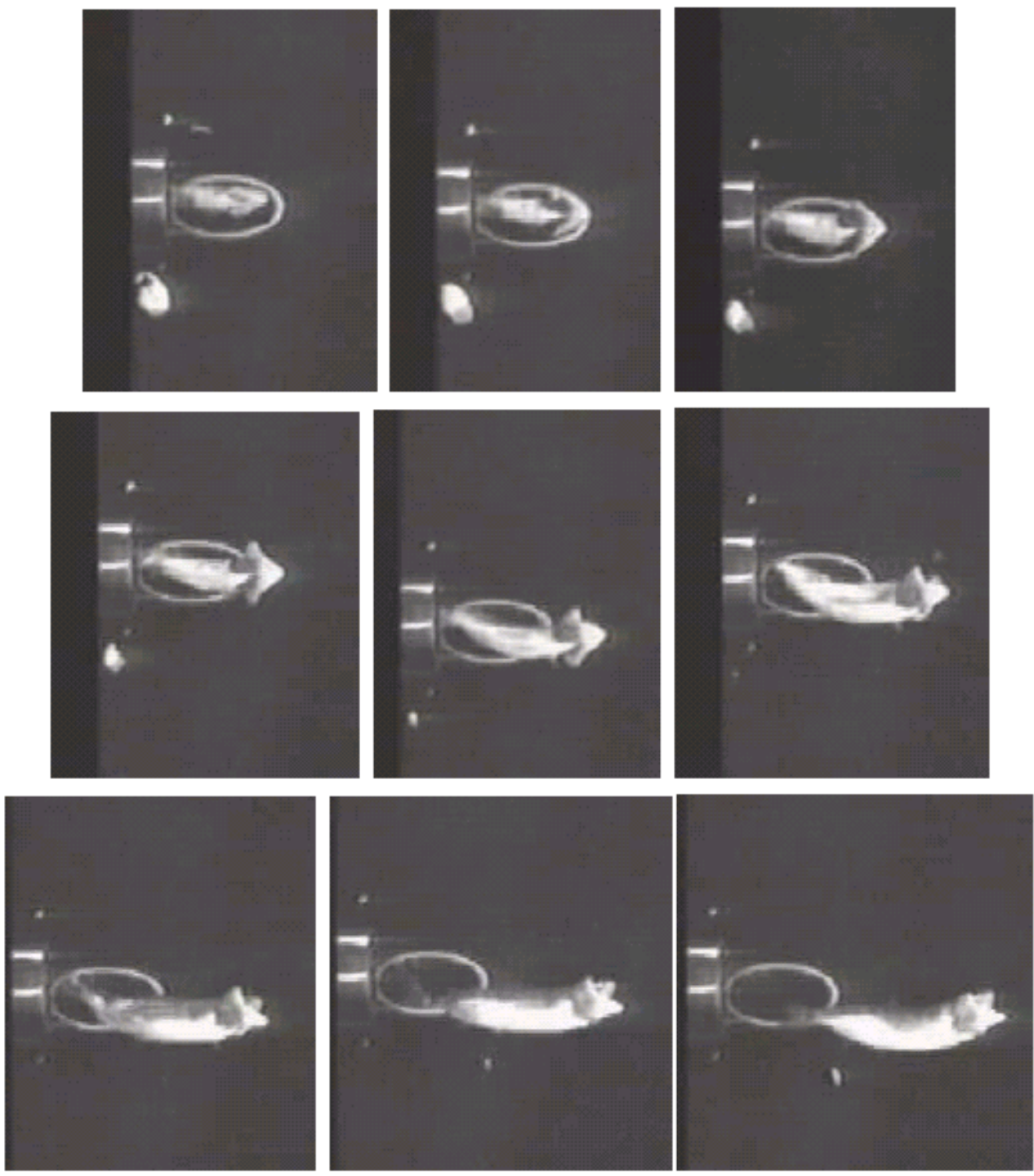

Figure 6. Examples of tissue damage to fish during turbine passage.

The technique is based on quantifying changes in a high-energy swimming burst (called C-shape, "fast-start" behavior, or startle response) that fish use to avoid predators. In this rapid reflex behavior, fish form a C-shape, then spring back out and swim away, often oriented 90 degrees from their original position (see Figure 7). Following exposures to non-injurious turbulence, changes in escape behavior are observed in a laboratory tank using a high-speed video camera. The recorded behavior responses are evaluated using an image analysis system for a range of responses, including time of first response, duration of response, completeness of C-shape, speed of C-shape formation, acceleration, velocity, relative position, and direction of escape. Initial experiments indicate that the first four measures are reliable, easy to measure, and can detect behavioral disruptions in a dose-response pattern related to turbulence intensity. Although the experiment used disorienting levels of turbulence (such as might 
ORNL 2002-04373/asb
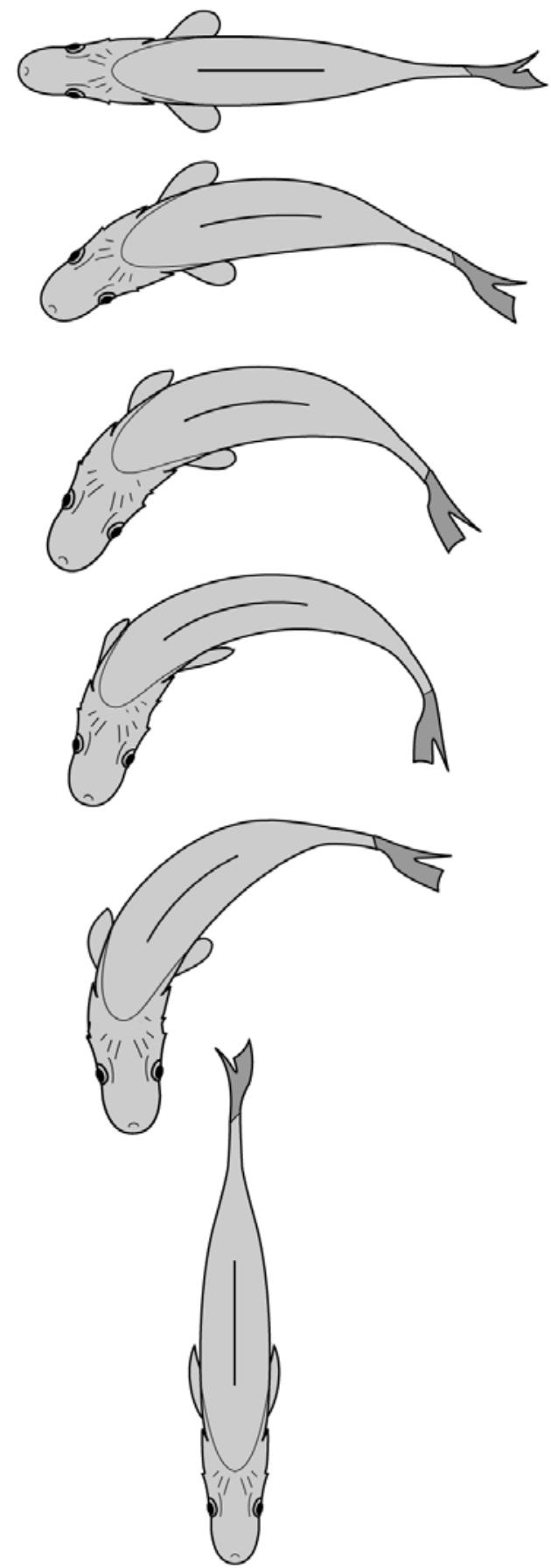

Figure 7. C-shaped swimming movement used to escape predators. 
occur in the draft tube and tailrace of a hydropower plant), the technique could potentially be used to assess a wide variety of physical stresses (sublethal shear or strike), temperature stresses, or chemical stresses (e.g., low dissolved oxygen).

\subsection{Draft Tube and Tailrace Studies}

Turbulence in the lower zones of hydropower plants is suspected to be a source of injury and mortality to downstream-migrating fish (Figure 2). The flow in draft tubes and tailraces of hydropower plants is dominated by large-scale, unsteady vortices induced by factors such as: residual swirl at the exit of the turbine runner, pressure gradients associated with the strong curvature of draft-tube walls, interaction of the flow with splitter plates and piers within the draft tube, and the complex interaction of the flow exiting the draft-tube with the tailrace. These vortices can have important biological effects as they could disorient fish and lead to increased predation losses. In addition, these complex flow structures could create regions of high instantaneous shear and turbulence, thus further contributing to fish injuries. This issue has been gaining increasing attention in the Pacific Northwest and elsewhere (Carlson 2001). For example, the Biological Opinion on the operation of the Federal Columbia River Power System calls for agencies to examine the effects of draft tubes and powerhouse tailraces on the survival of fish passing through turbines. This evaluation should include biological and hydraulic evaluations and, if warranted, implementation of measures to reduce the effects of turbine backroll on juvenile salmonid survival. Several projects were supported in FY 2002 to develop a better understanding of what is happening to fish in draft tubes and tailraces of hydropower facilities.

Characterizing Turbulent Flows in Full-Scale Turbines. In order to design controlled laboratory tests to study the biological effects of extreme turbulence, we must be able to describe the hydraulic conditions inside draft tubes and tailraces of turbine systems. An earlier review of the available data and analysis techniques concluded that adequate characterization did not exist. Therefore, a new effort was started in FY 2002 to obtain direct measurements of fully time-varying longitudinal and transverse velocity profiles inside a full-scale turbine draft tube.

The first phase of the study characterized the full-scale, time-varying nature of turbulent eddies in the lower zones of hydropower turbines. This was accomplished by collecting coincident three-dimensional velocity time series data at multiple points in the draft tube and tailwater. This unique approach is being pursued because: 1) draft tube turbulence is inherently a three-dimensional phenomenon and must be analyzed as such, 2) robust instrumentation to capture such data is becoming widely available, and 3) time series data lend themselves well to automated computations of biologically relevant indices of turbulence below hydropower turbines. The feasibility of using stateof-the-art Acoustic Doppler Velocity meters to make these flow measurements was examined in one of the Kaplan turbines at TVA's Melton Hill Dam on the Clinch River. Locations in the draft tube gate slots were measured simultaneously with locations in the tailwater to assess the performance of the measurement system and to establish 
preliminary procedures for computing relevant indices of turbulence. Velocity probes were suspended from rack-mounted streamlined struts in the draft tube gate slots and from floating or fixed structures in the tailwater. Velocities were measured for three turbine settings: (1) operation at peak turbine efficiency, (2) operation significantly below peak turbine efficiency, and (3) operation near the upper cavitation limit of the turbine.

The data acquisition and mechanical systems required to position and communicate with multiple Acoustic Doppler Velocimeters (ADV) in the draft tube gate slots were proven during FY 2002 field tests at Melton Hill Dam (Figure 8). Design of the tailrace suspension structure that will position ADVs in the tailrace was completed in FY 2002, but its deployment was postponed until the interpretation of draft tube measurements has been completed. In FY 2003, we will test alternative acoustic pulse schemes and signal processing algorithms to improve ADV performance in field. ADVs will also be tested in wake flow to aid in interpreting field measurements. When appropriate data sets are available, ORNL staff will develop post-processing algorithms to apply Proper Orthogonal Decomposition and other non-linear statistics for signal processing. Ultimately, this research will also contribute to improved discharge measurements used to optimize turbine energy outputs, which will be valuable to both federal and nonfederal operators.

Turbulence Measures. Physical models are an essential part of the design of hydraulic structures and machines such as hydroturbines. The U.S. Army Corps of Engineers North Pacific Division, with assistance from the DOE AHTS program, has built 1:25 scale models of turbine units for Bonneville Dam, McNary Dam, and Lower Granite Dam. A model of a Ice Harbor turbine unit is scheduled for construction in 2003. Historically, such models were primarily used to assess hydraulic conditions within the turbine units and to make measurements to better understand the forces acting on the turbines and supporting structures. More recently, these models have also been used to plan biological studies and to better understand the "biological performance" of hydroturbines.

Over the past 2 years, PNNL researchers have participated in the design and evaluation of the 1:25 physical turbine models. Tools and methods have been developed for the acquisition of 2D and 3D tracks of neutrally buoyant particles passing through these models. There is also a large biological response data set that was obtained during prototype testing of both original Kaplan and MGR runners at Bonneville Dam during the winter of $1999-2000$. The biological data set is unique since test fish were injected at specific locations at the test turbine's wicket gates, which controlled the portion of the runner and draft tube environment they experienced during passage. Studies are ongoing to acquire samples of the tracks of particles through the draft tube of the Bonneville turbine physical model. Of particular interest are any differences between the scales of turbulence and the 3D trajectories of particles passing through the model when operated with the original design runner in comparison to when operated with the a new minimum gap runner. Preliminary observations indicate significant changes in the turbulence structure in the draft tube as a function of turbine 
discharge and high rates of angular acceleration for particles passing near the runner hub. The injury rate and classification data obtained during this study will be reanalyzed with the observations of turbulence structure and other aspects of particle tracks obtained using the Bonneville physical turbine models.

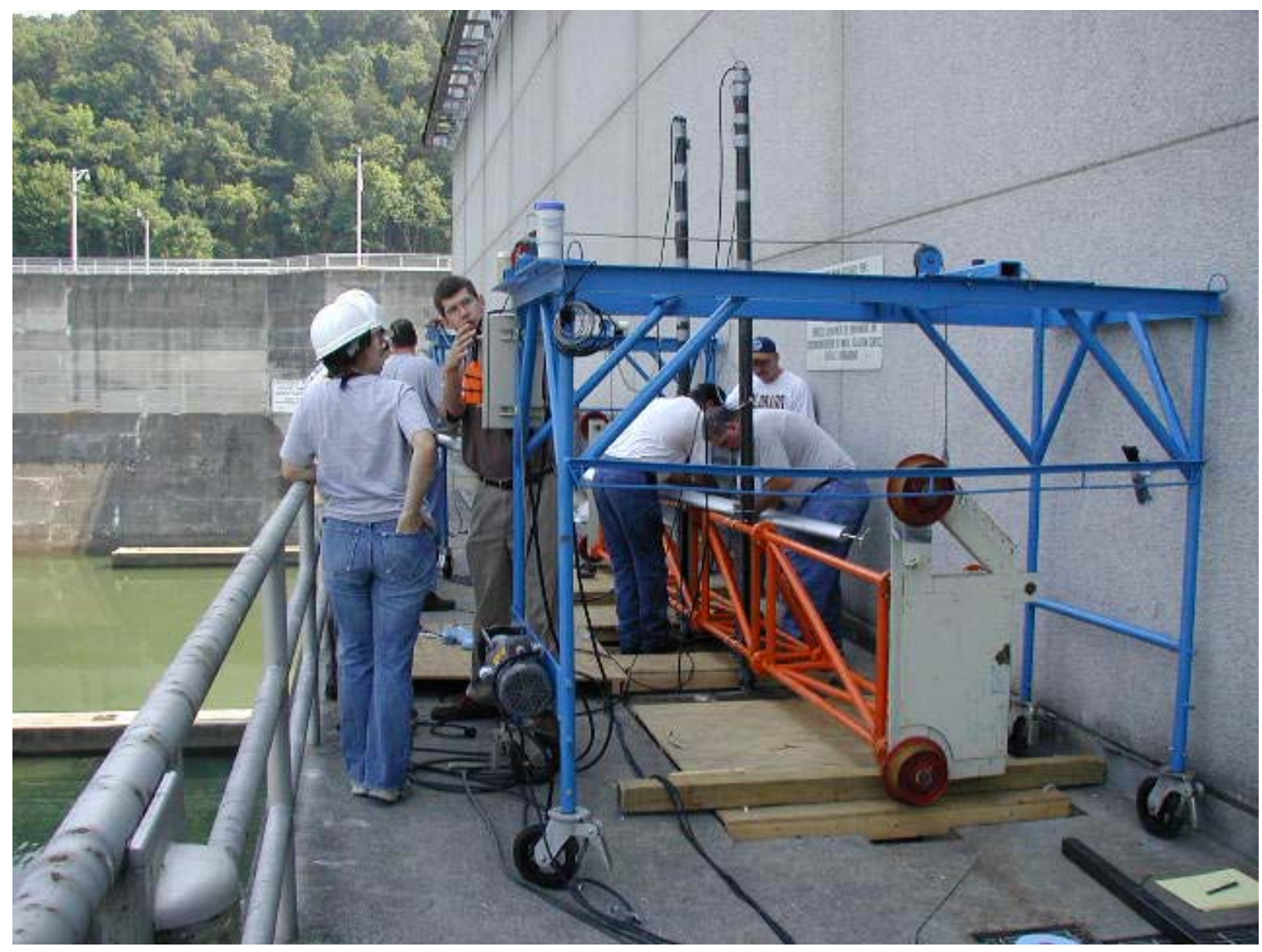

Figure 8. The use of Acoustic Doppler Velocimeters (ADVs) to measure turbulence in the draft tube of Melton Hill Dam, Tennessee.

\subsection{Computational Studies}

Computer simulation models are useful tools for studying phenomena that are difficult to observe directly, such as the hydraulic environment in turbines and the fate of fish in that environment. CFD tools are already used extensively in turbine design, but there is much room for improvement in these modeling techniques. Computer modeling is being used to complement field and laboratory studies and to improve overall understanding of the hydraulic environment experienced by fish. Exploratory, computational research is being pursued in three areas: 1) modification and extension of commercially available CFD methods to identify the location and magnitude of damaging shear; 2) prediction of unsteady, time-varying velocity fields; and 3) development of virtual fish simulations. 
Inventory of Damaging Shear Zones in Kaplan Turbines. In previous laboratory studies, biological criteria were developed to describe how fish respond to hydraulic forces inside hydropower turbines (Neitzel et al. 2000a,b; Fisher et al. 2000). In FY 2002, modeling studies were continued to develop and demonstrate computational methods for applying these biocriteria to turbine design. Voith, in cooperation with ORNL, developed CFD methods for predicting the location and magnitude of damaging shear to fish passing through hydropower turbines (Garrison et al. 2002). Commercially available CFD modeling and experimental data were utilized to locate and quantify shear areas within a turbine environment that, according to previously defined criteria, could be harmful to certain fish species. Two operating conditions for hydro turbines at Wanapum Dam were evaluated, optimum $(11,000 \mathrm{cfs})$ and high flow (17,000 cfs). Of the two conditions analyzed, the high flow condition contained significantly larger areas of damaging shear stress (Figure 9). Many shear zones that would be damaging to fish were located, including: 1) near the band at the trailing edge of the wicket gates 2 ) in the runner near the hub and periphery gaps, 3 ) in the blade wakes, 4) in the boundary layer on the blade surfaces, 5) under the hub in the draft tube, 6) at the leading edge of the draft tube piers, and 7) in a separated region of the flow near a draft tube pier. These methods will be applied to a wider range of operating conditions in the next phase of this study, and the results will be compared to field observations of fish injury at Wanapum Dam (i.e., Normandeau Associates, Inc. 1996).
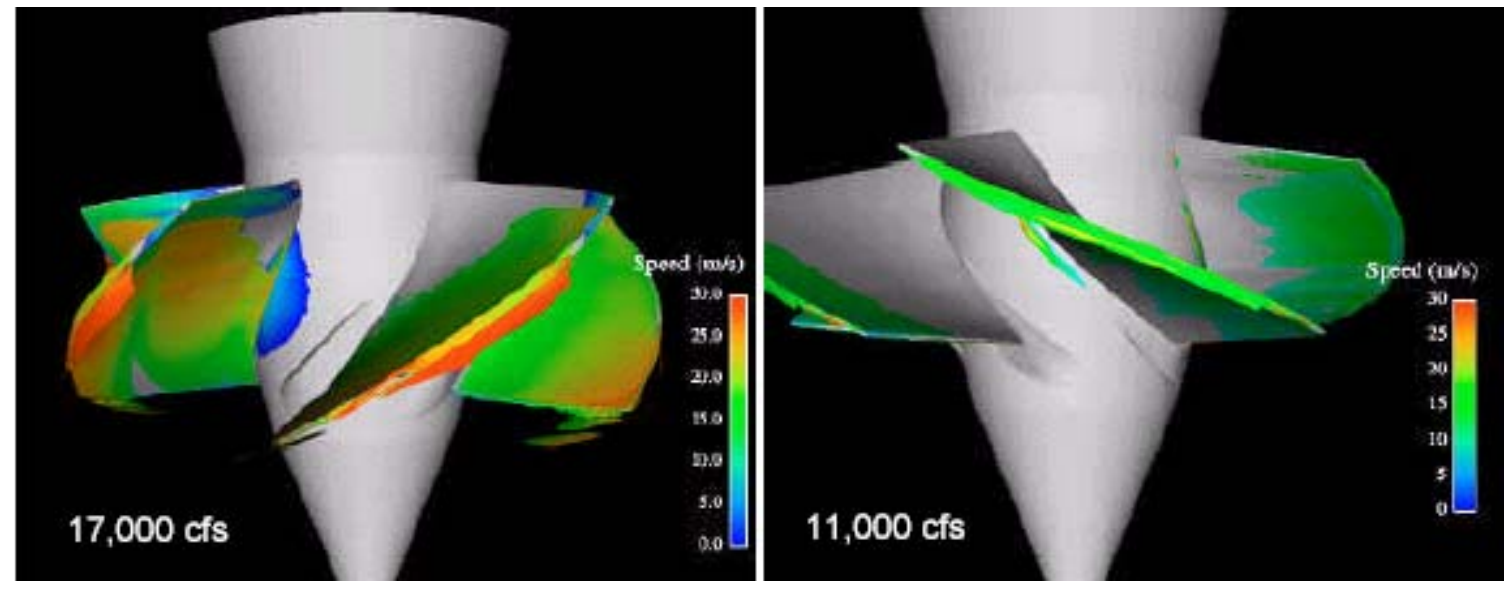

Figure 9. Damaging shear zones in Kaplan turbines. From Garrison et al. (2002).

Modeling Unsteady Hydraulics In Draft Tubes And Tailraces. The hydraulic environment inside turbines is poorly understood, especially with respect to the timevariable conditions that affect fish. Computer simulation models and visualization tools are very useful in understanding these hard-to-measure conditions.

This research is developing innovative computer models to predict and visualize time-varying, turbulent flow fields inside turbine systems, using Large Eddy Simulation (LES) techniques. The work is being carried out as a joint project between ORNL and 
Georgia Tech. To date, the modeling approach has been applied to data from the experimental flume at PNNL and to several available draft tube data sets. In the future, the computer codes will be further refined and tested on advanced, parallel-computing platforms and applied to more complex data sets. The specific focus will be on simulation of coupled draft-tube and tailrace environments under various turbine operating conditions (Figure 10). Calculations will be carried out on very fine computational meshes on ORNL's massively parallel supercomputers.

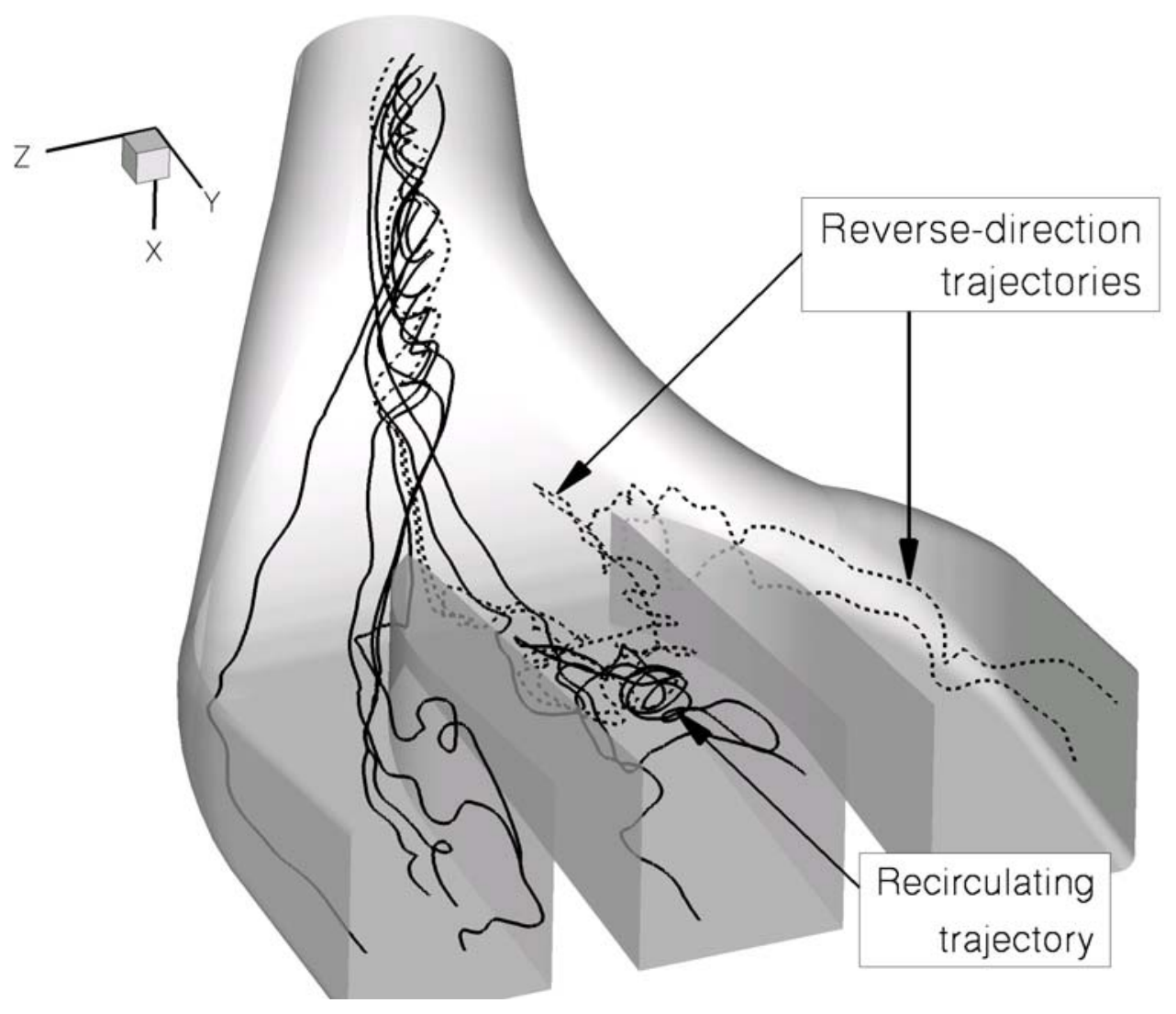

Figure 10. Reverse direction and recirculating particle trajectories in a simulation of water flow through the draft tube at Norris Dam. From Jones and Sotiropoulos (2002).

Interactions between Fish and Flow inside Turbines. This project is developing new simulation models of fish in turbulent flow fields that can predict biological effects inside turbine systems. It is another collaborative project between ORNL and Georgia Tech, and it relies on the unsteady CFD models to predict the timevarying velocity fields inside turbines. The unique aspect of this new fish modeling is that it will allow the simulated fish body to be fully (i.e., two-way) interactive with the velocity field (i.e., the presence of the fish modifies the surrounding velocity pattern and visa versa). 
The main activity for this project is development of a fluid-structure interaction model, which determines the deformation of the fish body directly from the flow-induced forces and moments. The immersed boundary method will be combined with domain decomposition techniques to facilitate the efficient resolution of the boundary layers near the fish body at realistically high Reynolds numbers. This step is essential to simulate the high-energy conditions inside full-scale turbines. The unsteady virtual fish (UVF) model will then be applied to the LES velocity fields that were measured in an experimental flume at PNNL, to explore the fish-flow interaction, to develop statistical estimates for various flow-induced loads, and to correlate the model predictions with video recordings and biological observations. The UVF model may also be applied to the unsteady, draft-tube flow fields observed in field studies at TVA's Melton Hill Dam.

Biomechanics of Fish Injury. Identification of conditions that cause injuries to fish in severe hydraulic environments (Cada et al. 1997) has been aided by recent studies conducted as elements of the DOE AHTS Program. These experiments related fish injuries to the fluid environment in a general manner; missing are detailed measurements of the displacement of the parts of the fish body, near-body velocity distribution, and how these are related to the observed injuries. Detailed measurements and computations are necessary to gain an improved understanding of the biomechanics of injury mechanisms and injury thresholds. Studies were initiated in FY2002 to develop and validate a fully-coupled computational fluid dynamics (CFD) and computational solid mechanics (CSM) model for simulating the response of a fish to turbulent flows. The CFD code uses the Arbitrary Eulerian-Lagrangian (ALE) method to calculate the motion of the flexible fish body through the fluid. The CSM code uses a nonlinear finite element method to compute the deformation of the fish body. Parallel to the computational work are a set of experiments using high-speed imaging to provide key data that will be used to validate the simulation model.

\subsection{Instrumentation and Monitoring Technology}

The Program's attention to understanding the fate of fish inside turbines has led to the need for new instrumentation and monitoring technology. Several unique R\&D efforts are being supported in this area.

Sensor Fish Development. The goal of the sensor fish development project is to link exposure conditions that fish experience during passage through turbines, spill, and other fish bypass environments and the consequences of that exposure. Since initial field trials at McNary Dam in 1999, the sensor fish device has undergone several design changes and has been deployed thousands of times through turbine, sluiceways, and in spill at Rock Island, Wanapum, McNary, The Dalles, and Bonneville Dams. The current model in use is an impact resistant $190 \mathrm{~mm}$ long and $50 \mathrm{~mm}$ diameter polycarbonate cylinder (Carlson and Duncan, 2002a) that weighs approximately $355 \mathrm{gm}$ in air but has only $3 \mathrm{gm}$ of excess mass in fresh water at $14^{\circ} \mathrm{C}$. The device contains a pressure transducer, and three linear accelerometers in a tri-axial configuration. Additional electronics provide power and digitally sample and store the 
time history of the response of the sensor. The pressure time history reveals the larger scale movements of the sensor in depth and is useful as a means to estimate the location of the sensor at points in time. The acceleration time history shows the duration and intensity of the turbulence the sensor encounters. All field tests to date have included tests of live fish exposed to the same general passage conditions. Two statistics obtained from sensor fish time histories show particular promise: 1) duration of exposure to high turbulence events, and 2) a turbulence index. Both of these measures are obtained by imposing a $3 g$ threshold on the acceleration magnitude and analyzing the remaining sequence of acceleration magnitude values.

Development of a smaller sensor fish device was completed in 2002 (Figure 11). The device has approximately the same mass as a yearling salmon smolt (approximately $30 \mathrm{gm}$ ) with less than $1 \mathrm{gm}$ excess mass in fresh water at $14^{\circ} \mathrm{C}$. This is important because inertial effects are evolving as an important injury mechanism for fish with differential effect depending upon fish mass (Carlson and Duncan, 2002b). This new sensor is also designed to be used as a gastric implant in post-spawning adult steelhead or "kelts".

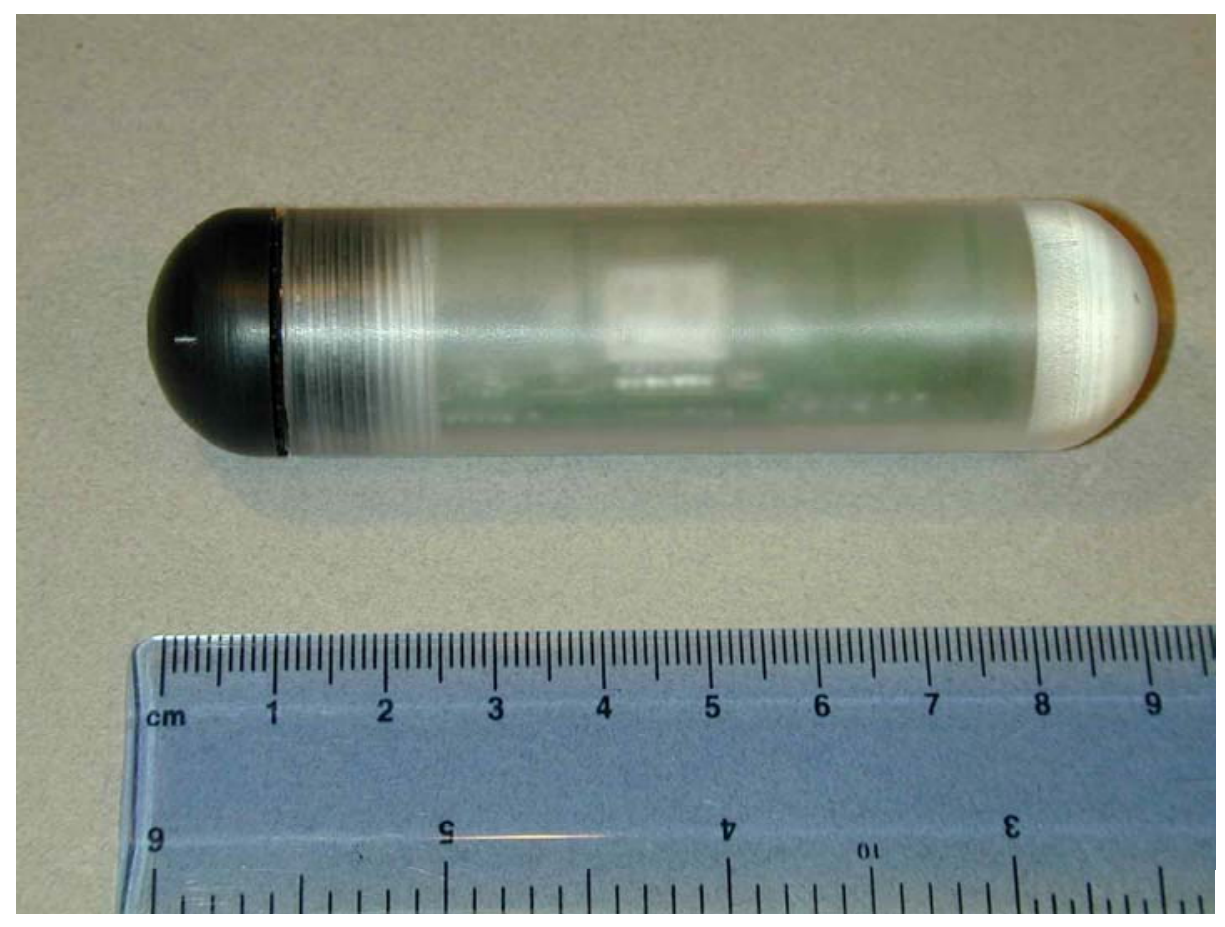

Figure 11. New, smaller sensor fish device.

An extension of the current sensor fish project is calibration of turbulence exposure duration and turbulence indices obtained by inertial particle tracking in CFD models. The calibration consists of extracting acceleration magnitude based measures similar to those obtained from sensor fish acceleration time histories and deriving the correlation function linking them for CFD simulations of the same spill conditions sampled using sensor fish and live fish. The linkage between the sensor fish time histories, live fish injury and mortality data, and CFD particle tracking statistics provides 
the means to link CFD model output with the consequences of passage to live fish. If successful, this method will permit the use of CFD models to predict the likely impact to fish of structural and operational alternatives for fish passage.

Pressure Sensitive Film. The injury mechanisms that a fish may experience as it passes through a turbine (i.e., shear stress, turbulence, changes in water pressure, grinding, and strike) can all be expressed in terms of pressure. The capability of pressure-sensitive films (PSF) to record pressures on the surface of a fishlike object were examined, as a possible technique for estimating the magnitudes of turbinepassage stresses. PSF is thin, flexible, and able to instantly and permanently record pressures. An impulse (strike) creates a red stain on PSF that is proportional to the pressure exerted (Figure 12). Individual PSFs are available in a range of sensitivities to pressure, that in total can detect pressures between $0.2 \mathrm{MPa}$ to $150 \mathrm{MPa}$ (29 to 21,756 psi). In the laboratory, we tested the responses of PSF to pre-determined pressures following stacking (different weights of film sandwiched together to detect a broader range of pressures) and packaging in a waterproof plastic pouch. In FY02, PSF packages were attached to sensor fish and passed through dam spillways at Bonneville and The Dalles dams on the Columbia River.

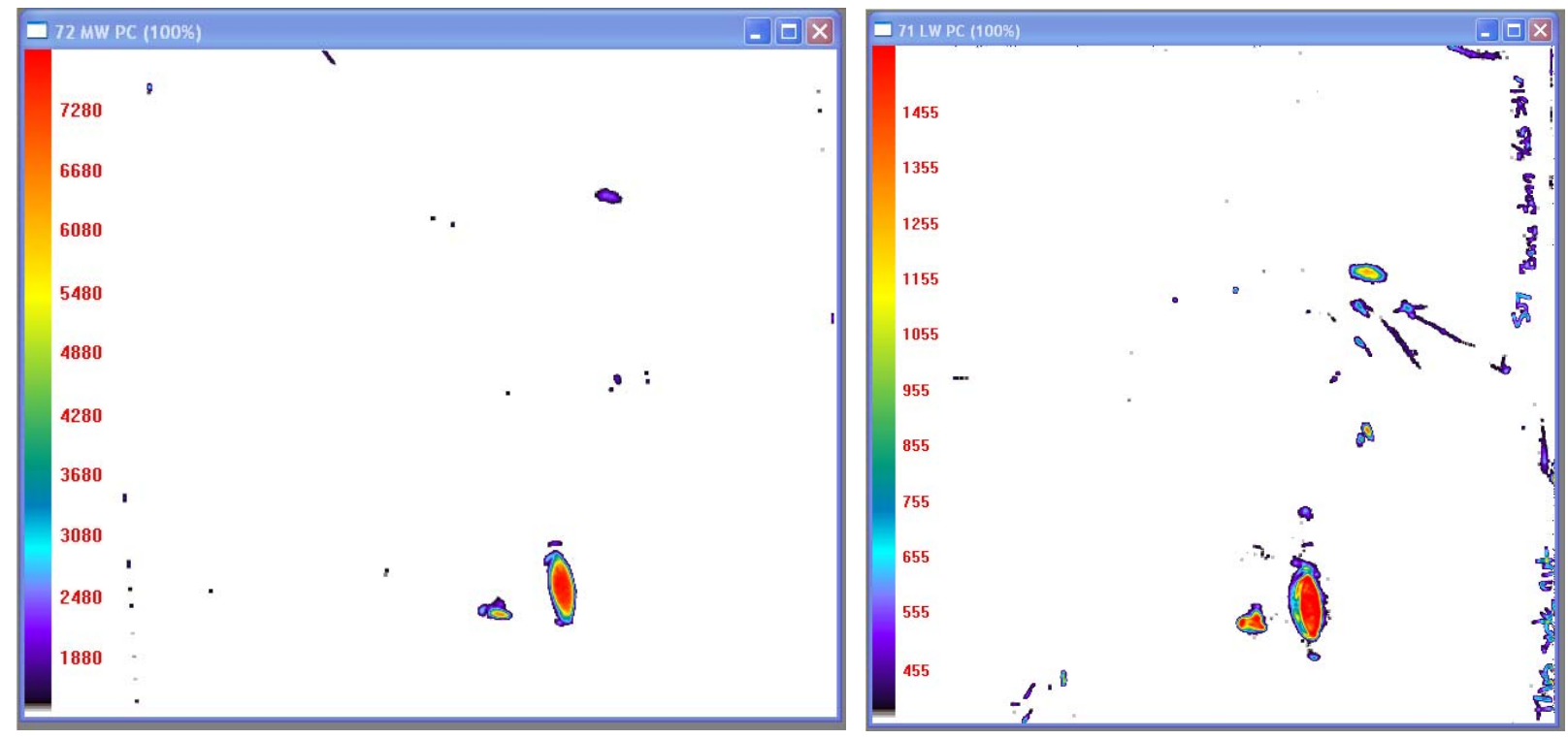

Figure 12. Pressure sensitive films wrapped around a sensor fish that passed down the Bonneville Dam spillway on August 28, 2002. Pressures registered by the films ranged from 360 psi (black areas) to 7700 psi (red spot).

Evaluation of Fish Passage in Turbines. Conditions that fish experience during passage through a turbine vary depending upon the design of the turbine and the way it is operated. Characterization of these conditions has been a 
challenge because of issues associated with placing instruments within a turbine. Of particular interest is the achievable spatial and temporal resolution in position estimates of fish and other objects.

To address this need, we conducted studies to resolve uncertainties related to the use of light emitting and ultrasonic technologies within the turbine environment, including the draft tube. We assessed the use of light-emitting tags (LET) for tracking objects through draft tubes and examined the feasibility of using ultrasonic tags and ultrasonic imaging sonar for characterizing flow fields and fish passage. We found that LEDs could be viewed in a high flow environment, e.g., from the wicket gate and approaching the turbine runner, using high-speed video cameras (Figure 13). Ultrasonic 3-D tracking systems show promise for tracking fish in the forebay and turbine intakes, but are susceptible to external noise. A new technology, DualFrequency Identification Sonar (DIDSON) shows promise for image acquisition in turbulent or turbid environments, for example providing information on the trajectory of a fish through draft tubes.

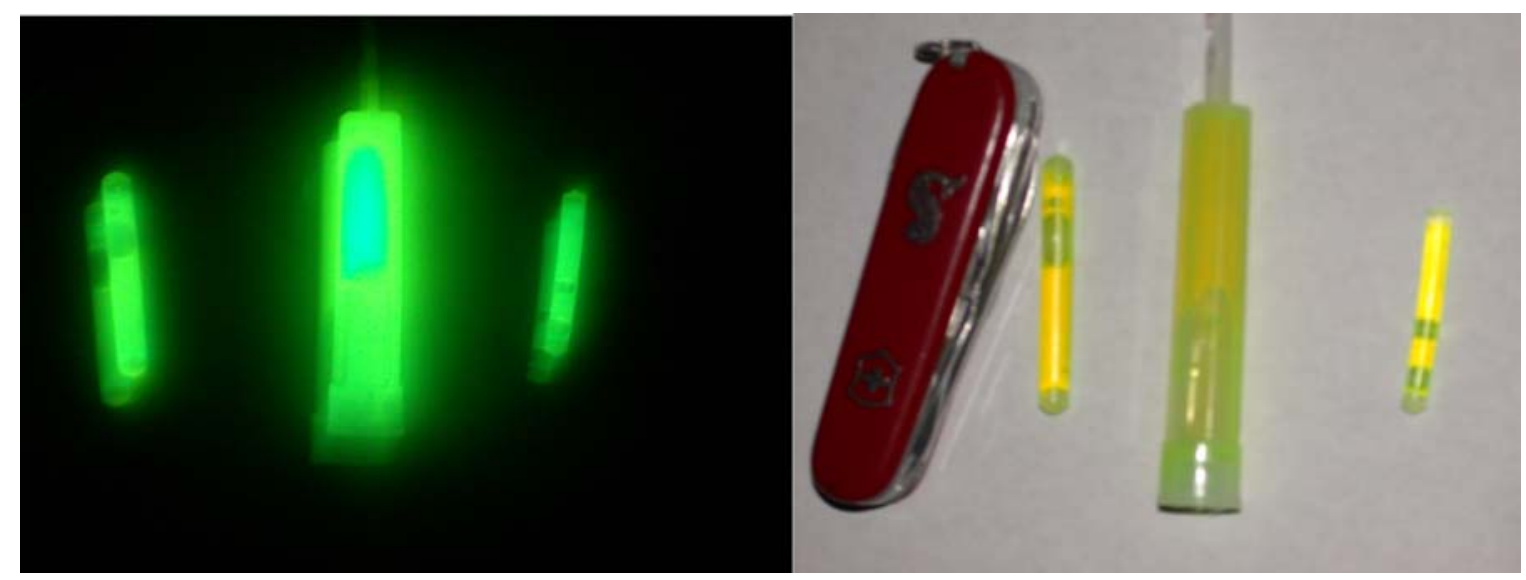

Figure 13. Green Cyalume chemical light sticks (2", 4", and 1.5" from left to right) used in feasibility testing at Bonneville and McNary Dams and in evaluation of camera tracking arrays. 


\section{ENVIRONMENTAL MITIGATION AND OTHER STUDIES}

The hydropower program includes a diverse array of other environmental studies supporting the program's goals. Although funding to support these other studies was limited in FY 2002, several important activities continued in this area.

\subsection{Mitigation Studies}

New research on the effectiveness of environmental mitigation practices was identified as an industry need in both the DOE-sponsored Hydropower R\&D Summit in November 2000 and in the R\&D Forum in Salt Lake City in July 2001. Therefore, the Program is supporting several mitigation studies.

DO Mitigation. The discharge of water with low dissolved oxygen (DO) concentrations can be addressed by a variety of structural and non-structural measures. An update of EPRl's review of structural mitigation techniques was published in 2002 (EPRI 2002). DOE is preparing a complementary report on non-structural approaches for addressing DO problems at hydropower facilities. For example, operational changes, such as fluctuating the timing and duration of generation flow releases or releasing water over spillways, can raise downstream DO concentrations (Peterson et al. 2001). Regulatory approaches might be used to resolve DO issues, including negotiating site-specific water quality standards, performing bioassessments as an adjunct to monitoring chemical parameters, and exploring the use of watershed-based water quality improvement strategies under the Total Maximum Daily Load (TMDL) Program. The report summarizes a recent EPA-sponsored study of water quality at hydropower projects in the Mississippi River basin, and evaluates the potential role of pollutant trading in improving reservoir water quality and the quality of releases from hydropower projects.

Instream Flow Requirements. DOE'S environmental mitigation studies were begun in 1991 but were postponed when work on advanced turbines was started. The research on instream flow requirements (IFRs) began in FY 2002 and is focusing on the costs, benefits, and effectiveness of the instream flow requirements that are placed on hydropower projects. Such studies have been consistently identified as high-priority needs by industry and other stakeholders, most recently in a letter from NHA to DOEEE (June 20, 2002). Instream flow requirements are the major reason that existing projects lose energy production during relicensing, therefore DOE attention is needed here to ensure regulations are balanced for both environmental protection and energy production.

A study plan for this project was completed at the end of FY 2002, incorporating consultation with industry, environmental groups, and other agencies that has occurred over the past year. Effort in FY 2002 included an update on the types of IFRs that are being applied to hydropower and the available data bases that may be used to quantify 
impacts on project operations. In FY 2003, we will select specific case study sites, acquire available data to estimate costs and benefits, and prepare a draft report that evaluated the feasibility of effectiveness determinations, based on initial applications, will be selected.

\subsection{Other Studies of Impacts to Fish}

Fish Guidance with Induced Turbulence. With joint funding from EPRI and the DOE hydropower program, the hypothesis was tested that a turbulent river could be simulated in a reservoir and the smolts would follow the turbulence to safe passage (Coutant 1998; Coutant and Whitney 2000). The rationale for this hypothesis is that turbulent flow is characteristic of natural migration corridors and that migratory fish have likely evolved an ability to sense directional cues from turbulent flows. Downstreammigrating smolts might be guided by inducing river-like turbulence and be directed away from turbine intakes, into safe dam bypasses, and through long reservoirs.

The use of hydraulic turbulence to guide steelhead smolts was tested in the forebay of a small hydroelectric plant in Michigan. The American Electric Power Company's 4,104-kW Buchanan Hydropower Project diverts water from the St. Joseph River through a 250-m intake canal from a small, 4-m-high impoundment. Smolts migrate downstream in April and May from hatchery stocking and natural reproduction upstream and many pass through the turbines when the plant is operating. The study tested the effectiveness of existing and induced hydraulic turbulence for guiding smolts in the plant's headrace. Hatchery-raised steelhead smolts were tagged with Cyalumne ${ }^{\mathrm{TM}}$ light sticks (Figure 14) and movement of individual fish was followed at night (manual observation and video) in relation to hydraulic features. Trajectories of fish tagged with light tags were followed during night-time migrations for 4 days in late April and early May 2002. Hydroacoustics was used to sample untagged migrants throughout the April-May 2002 migration season. Hydroacoustic transducers were placed at either side of the intake canal in an overlapping pattern to detect movement of untagged fish, both smolts and kelts (spawned-out adults), in the intake canal, in relation to hydraulic features.

This was an exploratory study intended to observe migrating smolts in the vicinity of a variety of turbulence-inducing structures, some already in place and some added. Tagged fish clearly followed hydraulic patterns induced by a debris boom, bridge abutments, and a turbulence-inducing baffle device we installed (hydroacoustic data have yet to be analyzed). These successful preliminary results indicate measures that might be evaluated further for permanent fish protection at this and other water intakes, thus allowing continued "fish-friendly" operation during fish migrations. 


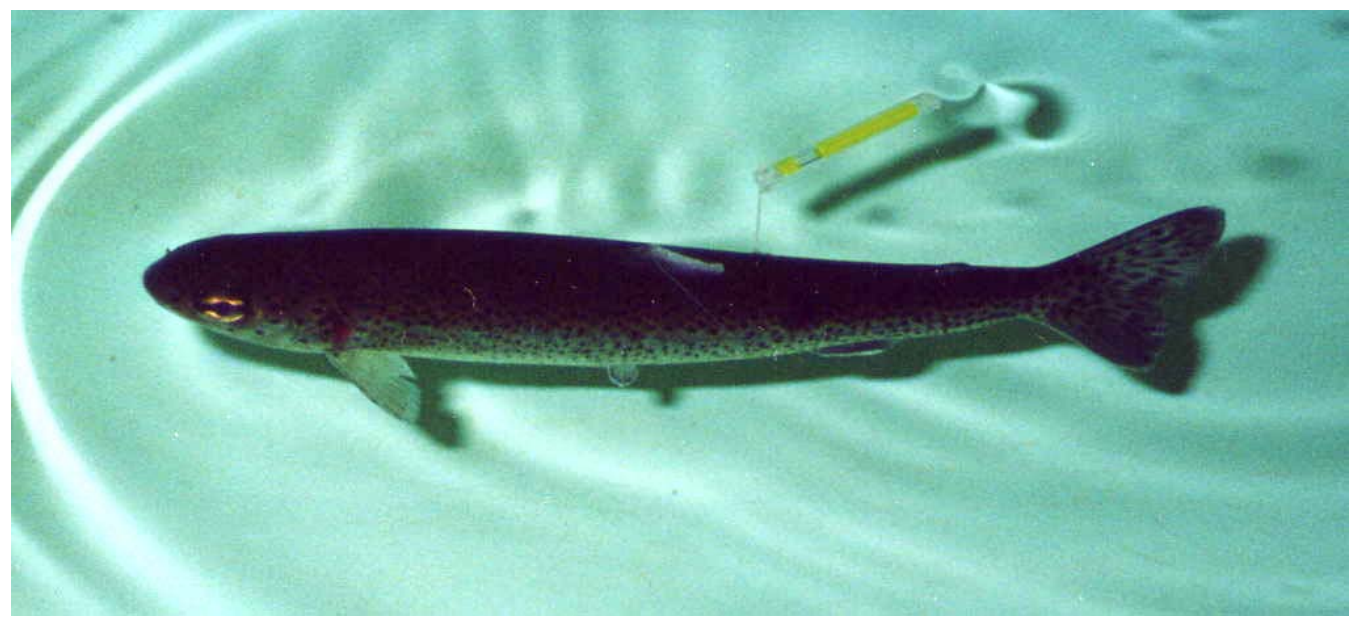

Figure 14. Steelhead smolt tagged with a light tag. 


\section{LOW HEAD/LOW POWER HYDROPOWER TECHNOLOGY}

Most of the current activities of the DOE hydropower program are aimed at conventional hydropower plants that use conventional turbines and sites. There is also a need to develop unconventional turbine designs, such as low power $(<1 \mathrm{MW})$ and low head ( $<30$ feet) sites, free-flow turbines (no impoundments needed), and microhydropower. Generally, smaller sites have fewer environmental problems, although some individual sites may still have specific environmental issues. New turbine designs have been developed that may have low environmental impact, and some types of unconventional hydropower may be suitable for implementation as distributed power sources. The resources and potential market of this new technology need to be further understood.

In FY 2002, DOE continued an assessment of potential resources appropriate for low power and low head development. Three general types of hydropower systems have been identified for the purposes of this study: (1) conventional, (2) unconventional and (3) microhydropower. Conventional systems utilizes existing technology for heads greater than eight feet but less than 30 feet. Unconventional systems use the kinetic energy from water in motion (free-flowing systems). Microhydropower sites are $100 \mathrm{~kW}$ or less with no restriction on head. This activity will identify the total potential resource and then apply a screening process to each type of technology.

Each resource type is associated with specific technologies that have specific site requirements (i.e., flows, depths, head, etc.). Additionally, when other site selection criteria are applied, the number of resources available for development are reduced. The study's results will include the number of sites for each development type and an estimate of potential power for each site, which will be used to calculate total resource potential. The data are being presented by region. The report for Low Head/Low Power Hydropower Resource Assessment of the Arkansas White Red Hydrologic Region was issued July 2002 (Hall et al. 2002a). The report for Low Head/Low Power Hydropower Resource Assessment of the Pacific Northwest Hydrologic Region was issued September 2002 (Hall et al. 2002b). The remaining 16 Hydrologic Regions in the lower 48 states will be completed in FY-2003. 


\section{TECHNOLOGY TRANSFER AND OUTREACH}

The transfer of new information to the hydropower community has always been an important component of the DOE hydropower program. This transfer is carried out by participating in technical conferences, publications, ad hoc meetings to coordinate interagency research activities, and on-call assistance from DOE and National Laboratory staff. The publications that are generated as part of this technology transfer function have been cited throughout the text and are listed in the References Cited section of this annual report. Other examples of these activities for FY 2002 are highlighted below.

\subsection{Interagency Coordination and Outreach}

Hydropower program personnel were involved in these activities in FY 2002.

Conference planning and participation. Staff from INEEL, ORNL, and PNNL serve on the organizing committees for several annual meetings, including National Hydropower Association's Annual Conference that is held in Washington, DC, and the biennial Waterpower and HydroVision conferences. Other conference participation in FY-2002 included: American Fishery Society's $4^{\text {th }}$ Bioengineering Symposium; The Search for Northwest Fish Passage: Resolving Mitigation Issues with Hardware Technology and Computer Models Symposium; National Energy Policy Implementation Plan Workshop; Western Division of American Fisheries Society Annual Meeting; and Illinois Renewables Energy Conference. Invited briefings were also provided at several industry meetings.

Hydropower Computer Codes Conversions. Existing computer codes for the Hydropower Evaluation Software (dBase III) was converted into Visual Basic. The new software and user's manual was issued June 2002 (Zane 2002). The Hydro-Econ (Basic) and Hydro-Calc (Basic) are being converted into Visual Basic. The purpose is to make the existing Resource Assessment software, the Energy Analysis software and the Economic Analysis Software more user friendly on today's computer operating systems.

Education Activities. The DOE hydropower program provided scholarship funds in support of the turbine contest at HydroVision 2002 and the Foundation for Water and Energy Education's Hydropower Essay Contest.

\subsection{Technical Support to DOE}

A variety of ad hoc technical support is provided to DOE through the hydropower program, such as the monitoring of research outside DOE (e.g., Cada and Rinehart 2000), annual reporting (e.g., Sale et al. 2002) and other miscellaneous activities. The FY 2002 activities in this area are described here. 
Proposal review. DOE received several unsolicited proposals throughout the year, including R\&D ideas for unconventional turbine technology. National Laboratory staff and DOE conducted technical reviews of these proposals and provided comments back to the proposers. The proposers were also advised of the current and planned solicitations so that they could participate in this process.

Web site development and usage. The program maintains an official Hydropower web site (http://www.eere.energy.gov). Several updates and changes were made to the site in FY 2002 in the subject areas of Hydropower Facts, the Advanced Hydropower Turbine Systems, and Hydropower Resource Assessment. Reports on the Program's significant new research results were added, including the new DOE reports cited in this Annual Report. Other papers that program staff published in professional and trade journals over the past year were also added to the web site.

The latest statistics on user access to DOE's hydropower web site indicate steady interest and access by users worldwide. The hydropower web site received a total of 758,300 hits between November 2000 and September 2001, and averaged 69,000 hits per month.

Program Reviews and Planning Documents. Two program review meetings were conducted (December 2001 and August 2002). The planning documents prepared included: Hydropower Program FY-2002 Annual Operation and Management Plan; and Draft Hydropower Program Research and Development Strategic Plan FY 2002 - FY 2007. 


\section{FUTURE ACTIVITIES}

DOE plans to: 1) complete the biological and engineering testing of the new runner designed by ALDEN/Concepts NREC, 2) continue cooperative studies with the Corps and its Turbine Survival Program, and 3) continue cost-shared testing of the biological performance of new hydropower turbine technology. The primary focus of these activities will be to determine the fish passage characteristics of new turbine technology and to verify the fish friendliness of these new designs.

With regard to basic and applied R\&D, the combined field, laboratory, and computational research described here will continue in future years. Specific studies will be designed to understand the turbulent environment downstream of the turbine runners, in the draft tube and in the tailrace of hydropower plants. This research is likely to include both physical characterization of existing plants and additional biological studies to further define, enhance, and test the biological criteria for the strike injury mechanism. The work on advanced sensors will also continue, developing better ways to track fish through turbine systems and relate fish response to the cumulative stresses from hydropower systems.

At the North American Hydro Research and Development Forum convened in 1992, the hydropower industry reviewed research efforts in the industry and identified research needs. A smaller industry-government R\&D summit was held in November 2000 to reexamine research needs, and this planning effort was repeated after Waterpower XII in Salt Lake City in July 2001. Many of the issues identified at these meetings continue to be addressed by the DOE Hydropower program and remain targets for future research efforts, as resources allow. 


\section{CONCLUSIONS}

The DOE hydropower program continues to make unique and important contributions to clean energy production in the U.S. By working toward technology improvements that can reduce environmental problems, the program is helping position hydropower as an acceptable, renewable, domestic energy choice. Program activities are closely coordinated with industry, other federal agencies, and public interest groups to ensure an efficient, open, and scientifically sound research agenda. DOE funding is leveraged with cost-sharing whenever possible, and peer-review processes are used in making funding decisions.

The key successes in FY 2002 were:

- Biological and engineering tests at the pilot-scale test facility at Alden Research Laboratory, to evaluate the environmental and engineering performance of the new Alden/Concepts NREC runner (Hecker et al. 2002).

- Publication of new biological response studies of the effects of pressure and dissolved gas supersaturation on fish passing through hydropower turbines (Abernethy et al. 2001, 2002).

- Deployment of the phase II sensor fish device at Columbia River dams to evaluate hydraulic forces present in spillways and a high-volume outfall.

- Collaboration with industry and other federal agencies in two successful workshops to identify future R\&D needs for hydropower.

- Establishment of financial assistance agreements for field testing of large turbines (Box Canyon Project, Osage Project, and Wanapum Project).

- Development of a methodology for low head/low power hydropower resource assessment and completion of two hydrologic regions. 


\section{REFERENCES CITED}

Abernethy, C. S., B. G. Amidan, and G. F. Cada, 2001, Laboratory Studies of the Effects of Pressure and Dissolved Gas Supersaturation on Turbine-passed Fish. DOE/ID-10853, U.S. Department of Energy Idaho Operations Office, Idaho Falls, Idaho.

Abernethy C. S., B. G. Amidan and G. F. Cada. 2001. Laboratory Studies of the Effects of Pressure and Dissolved Gas Supersaturation on Turbine-Passed Fish. PNNL-13470, Pacific Northwest National Laboratory, Richland, WA.

Abernethy C. S., B. G. Amidan, and G. F. Cada. 2002. Simulated Passage Through A Modified Kaplan Turbine Pressure Regime: A Supplement to "Laboratory Studies of the Effects of Pressure and Dissolved Gas Supersaturation on Turbine-Passed Fish". PNNL-13470-A, Pacific Northwest National Laboratory, Richland, WA.

Brookshier, P. A., J. V. Flynn, and R. R. Loose, 1995, " $21^{\text {st }}$ Century Advanced Hydropower Turbine System," Proceeding of Waterpower '95, American Society of Civil Engineers, New York, New York, pp. 2003-2008.

Cada, G. F., 1990, "A Review of Studies Relating to the Effects of Propeller-Type Turbine Passage on Fish Early Life Stages," North American Journal of Fisheries Management 10(4):418-426.

Cada, G. F., C. C. Coutant, and R. R. Whitney, 1997, Development of Biological Criteria for the Design of Advanced Hydropower Turbines. DOE/ID-10578, U.S. Department of Energy Idaho Operations Office, Idaho Falls, Idaho.

Cada, G. F., 1998, "Better Science Supports Fish-Friendly Turbine Designs," Hydro Review XVII (6):52-61.

Cada, G. F., and B. N. Rinehart, 2000, Recent R\&D Advances in Turbine Passage Technology. DOE/ID-10753, U.S. Department of Energy Idaho Operations Office, Idaho Falls, Idaho.

Cada, G. F., G. L. Sommers, and M.J. Sale, 2001, "What's Going On in There? Efforts to Describe the Experiences of Turbine-Passed Fish," Proceedings of Waterpower XII, HCl Publications, Inc. Kansas City, Missouri.

Cada, G. F., 2001, "The development of advanced hydroelectric turbines to improve fish passage survival," Fisheries 26(9)14-23.

Carlson, T. J., 2001, Proceedings of the Turbine Passage Survival Workshop, Portland, 
Oregon, June14-15, 2000. Prepared for the U.S. Army Corps of Engineers, Pacific Northwest National Laboratory, Richland, Washington.

Carlson, T. J. and J. P. Duncan. 2002a. Characterization of the Hydraulic Environment Experienced by Fish During Passage in Spill at Rock Island Dam. Report to Public Utility District No. 1 of Chelan County, Wenatchee, WA.

Carlson, T. J. and J. P. Duncan. 2002b. Characterization of the Wanapum Dam TopSpill Fish Passage Environment, April 2002. Report to Grant County Public Utility District Ephrata WA.

Conner, A. M., J. E. Francfort, and B. N. Rinehart, 1998, U.S. Hydropower Resource Assessment Final Report. DOE/ID-10430.2, for the U.S. Department of Energy Idaho Operations Office, Idaho Falls, Idaho.

Cook, T. C., G. E. Hecker, H. B. Faulkner, and W. Jansen, 1997, Development of a More Fish Tolerant Turbine Runner, ARL Report No. 13-97/M63F, for the U.S. Department of Energy Idaho Operations Office by Alden Research Laboratory, Inc., Holden, Massachusetts.

Cook, T. C., S. A. Cain, P. Fetfatsidis, G. E. Hecker, and P. S. Stacy, 2000, Final Turbine and Test Facility Design. Final report to the Idaho Operations Office, U.S. Department of Energy by Alden Research Laboratory, Inc. and Northern Research and Engineering Corporation, Holden, Massachusetts. August 2000.

Coutant, C. C., 1998, Turbulent attraction flows for juvenile salmonid passage at dams. ORNL/TM-13608, Oak Ridge National Laboratory, Oak Ridge, Tennessee.

Coutant, C. C., and R. R. Whitney, 2000, "Fish Behavior in Relation to Passage Through Hydropower Turbines: A Review," Transactions of the American Fisheries Society 129:351-380.

Energy Information Agency (EIA), 2002, Data for 1999 retrieved from the Internet, http://www.eia.doe.gov/cneaf/electricity/epav1/elecprod.html and http://www.eia.doe.gov/cneaf/electicity/epm/epmt05p1.html, January 16, 2002.

EPRI, 2002, Maintaining and Monitoring Dissolved Oxygen at Hydroelectric Projects: Status Report No. 1005194, Palo Alto, California.

Fisher, R., D. Mathur, P. G. Heisey, R. Wittinger, R. Peters, B. Rinehart, S. Brown, and J. R. Skalski, 2000, "Initial Test Results of the New Kaplan Minimum Gap Runner Design on Improving Turbine Fish Passage Survival for the Bonneville First Powerhouse Rehabilitation Project," Proceedings of the $20^{\text {th }}$ IAHR Symposium on Hydraulic Machinery and Systems, International Association of Hydraulic Research, Charlotte, North Carolina, Aug. 6-9, 2000. 
Francfort, J. E., G. F. Cada, D. D. Dauble, R. T. Hunt, D. W. Jones, B. N. Rinehart, G. L. Sommers, and R. J. Costello, 1994, Environmental Mitigation at Hydroelectric Projects, Vol. II. Benefits and Costs of Fish Passage and Protection. DOE/ID10360(V2), U. S. Department of Energy Idaho Operations Office, Idaho Falls, Idaho.

Franke, G. F., D. R. Webb, R. K. Fisher, D. Mathur, P. N. Hopping, P. A. March, M. R. Headrick, I. T. Laczo, Y. Ventikos, and F. Sotiropoulos, 1997, Development of Environmentally Advanced Hydropower Turbine System Concepts. Report No. 2677-0141, Voith Hydro Inc., prepared for the U.S. Department of Energy Idaho Operations Office, Idaho Falls, Idaho.

Galindo, E. and B. Rinehart, 2001, Indian Summer VI, Sho-Ban School, Fort Hall, Idaho.

Garrison, L. A., R. K. Fisher, Jr., and W. L. Waltersdorff, 2002, Computational methods for predicting damaging shear to fish in hydropower turbines: I. Feasibility study for Kaplan turbines. DOE/ID-10972. Final report on subcontract 4000000576 by Voith Siemens Hydro Power Generation, Inc., U.S. Department of Energy Idaho Operations Office, Idaho Falls, Idaho, (in press).

Hall, D.G., G. R. Carroll, S. J. Cherry, R. D. Lee, and G. L. Sommers, 2002a, Low Head/Low Power Hydropower Resource Assessment of Arkansas White Red Hydrologic Region. DOE/ID-11019, U.S. Department of Energy Idaho Operations Office, Idaho Falls, Idaho.

Hall, D.G., G. R. Carroll, S. J. Cherry, R. D. Lee, and G. L. Sommers, 2002b, Low Head/Low Power Hydropower Resource Assessment of The Pacific Northwest Hydrologic Region. DOE/ID-11037, U.S. Department of Energy Idaho Operations Office, Idaho Falls, Idaho.

$\mathrm{HCl}$ (HCl Publications, Inc.), 1992, Repowering Hydro Through Research and Development: Viewpoints of the U.S. Hydroelectric Industry. Report to the U.S. Department of Energy. HCl Publications, Inc., Kansas City, Missouri.

Hecker, G. E., T. C. Cook, and W. Jansen. 1997. A New Fish Friendly Turbine Runner. p. 383 - 391 IN Waterpower '97, Proceedings of the International Conference on Hydropower, D.J. Mahoney (ed.), American Society of Civil Engineers, New York, New York.

Hecker, G., S. Amaral, P. Stacy, T. Cook, M. Metzger, and B. McMahon, 2002, Engineering and Biological Evaluation of the Alden/Concepts NREC turbine. Proceedings of HydroVision 2002, HCl Publications, Inc., Kansas City Missouri. 
Jones, S. C., and F. Sotiropoulos. 2002. Large-eddy simulation of turbulent circular jet flows. DOE/ID-10971. Final report for Project E-20-M94 by The Georgia Institute of Technology, U.S. Department of Energy Idaho Operations Office, Idaho Falls, Idaho, (In press).

Jones, S. C., A. N. Gilmanov, J. Paik, F. Sotiropoulos, and M. J. Sale, 2002, Modeling the passage of fish through hydropower facilities. Proceedings of Bioengineering Symposium IV of the American Fisheries Society, Bethesda, Maryland.

Mattice, J. S., 1991, "Ecological Effects of Hydropower Facilities," Chapter 8 In J. S. Gulliver and R. E. A. Arndt (eds.), Hydropower Engineering Handbook, McGrawHill, Inc., New York, New York.

Neitzel, D. A., D. Dauble, M. Richmond, and G. Cada, 2000a, "Developing Biological Specifications for Fish Friendly Turbines," Proceedings of HydroVision '00, $\mathrm{HCl}$ Publications, Kansas City, Missouri.

Neitzel, D. A., M. C. Richmond, D. D. Dauble, R. P. Mueller, R. A. Moursund, C. S. Abernethy, G. R. Guensch, and G. F. Cada, 2000b, Laboratory Studies on the Effects of Shear on Fish: Final Report, DOE/ID-10822, U.S. Department of Energy Idaho Operations Office, Idaho Falls, Idaho.

Normandeau Associates, Inc., J. R. Skalski, and Mid Columbia Consulting, Inc., 1996, Fish survival investigation relative to turbine rehabilitation at Wanapum Dam, Columbia River, Washington. Prepared for Grant County Public Utility District No. 2, Ephrata, Washington, December 1996, 63 pp. + appendices.

Odeh, M., 1999, A Summary of Environmentally Friendly Turbine Design Concepts. DOE/ID/13741, U.S. Department of Energy, Idaho Operations Office, Idaho Falls, Idaho.

Peterson, M. J., G. F. Cada, and M. J. Sale, 2001, "Non-Structural Approaches for Addressing Dissolved Oxygen Concerns at Hydropower Facilities," Proceedings of Waterpower XII, HCl Publications, Inc. Kansas City, Missouri.

Sale, M. J., G. F. Cada, D. D. Dauble, B. N. Rinehart, G. L. Sommers, J. V. Flynn, and P. A. Brookshier, 2001, DOE Hydropower Program Annual Report for FY 2001. DOE/ID-10863, U.S. Department of Energy Idaho Operations Office, Idaho Falls, Idaho.

Sale, M. J., G. F. Cada, L. H. Chang, S. W. Christensen, J. E. Francfort, B. N. Rinehart, S. F. Railsback, and G. L. Sommers, 1991, Environmental Mitigation at Hydroelectric Projects, Vol. I, Current Practices for Instream Flow Needs, Dissolved Oxygen, and Fish Passage. DOE/ID-10360, U.S. Department of Energy, Idaho Falls, Idaho. 
Sale, M. J., G. F. Cada, B. N. Rinehart, G. L. Sommers, P. A. Brookshier, and J. V. Flynn, 2000, "Status of the U.S. Department of Energy's Advanced Hydropower Turbine Systems Program," Proceedings of the $20^{\text {th }}$ IAHR Symposium on Hydraulic Machinery and Systems, International Association of Hydraulic Research, Charlotte, North Carolina, Aug. 6-9, 2000.

Sale, M. J., G. F. Cada, T. J. Carlson, D. D. Dauble, R. T. Hunt, G. L. Sommers, B. N. Rinehart, J. V. Flynn, and P. A. Brookshier, 2002, DOE Hydropower Program Annual Report for FY2001. DOE/ID-10992, U.S. Department of Energy Idaho Operations Office, Idaho Falls, Idaho.

Zane, J. L. 2002, Uniform Criteria for U.S. Hydropower Resources Assessment Hydropower Evaluation Software (HES) User's Manual. DOE/ID - 10338 (rev.1) U.S. Department of Energy Idaho Operations Office, Idaho Falls, Idaho. 


\section{Appendix A Renewable Indian Energy Resources Program}

The U. S. Department of Energy, Idaho Operations Office (DOE-ID) administers a program of federal funding for a group of Alaska projects. Federal funds are awarded subject to the availability of local funds to share project costs. These projects include hydroelectric installations, diesel generating facilities, and transmission lines. DOE-ID manages the distribution of the federal funds and provides technical assistance to help the communities receiving federal funds efficiently use the available financial resources. Summary descriptions of the projects follow (Table A-1).

Nome Diesel Enhancement Project. Nome Joint Utility System's planned Nome Diesel Enhancement Project is located in Nome, Alaska. The project consists of the upgrade of an existing diesel generator from $3,600 \mathrm{~kW}$ (720 rpm) to 4,400 kW (900 $\mathrm{rpm}$ ). The upgrade will also retrofit the generator for waste heat recovery and commercial heating. Performance monitoring for two years will provide new data on costs, maintenance requirements, and energy production that can be applied to similar projects. The project is estimated to offset 2.4 million pounds of $\mathrm{CO}_{2}$ emissions per year at an effective residential power rate of $\$ 0.146 / \mathrm{kWh}$.

Old Harbor Project.

Old Harbor Hydro Plant - Alaska Village Electric Cooperative's (AVEC) planned Old Harbor Hydro Plant is to be located on Kodiak Island near Old Harbor, Alaska. The plant includes a 500-kW impulse turbine and generator unit operating with a 768-foot design head. When fully operational, the project will produce about 3,000 MWh/yr and displace about 200,000 gallons/yr of diesel fuel.

Scammon Bay Hydro Plant - AVEC's planned Scammon Bay Hydro Plant is to be located on Kodiak Island near Scammon Bay, Alaska. The plant includes a 100-kW impulse turbine and generator unit.

Power Creek Project. The Cordova Electric Cooperative developed this 6-MW hydropower project near Cordova, Alaska. The project includes two 3-MW horizontal Francis turbines with a design heads of $300 \mathrm{ft}$ and an annual average generation of $25,000 \mathrm{MWh}$. This generation will displace diesel-powered generation. Construction was completed on this project in December 2001.

Pyramid Creek Project. Unalaska Utilities' planned hydropower project is located on Unalaska Island near Dutch Harbor about 800 miles southwest of Anchorage. The project includes a $600-\mathrm{kW}$ impulse turbine and generator unit operating on a $400-$ foot design head and generating about $2,800 \mathrm{MWh} / \mathrm{yr}$. This project will eventually displace 254,000 gallons of diesel fuel per year. 
Reynolds Creek Project. Phase I of Haida (Native American) Corporation's Reynolds Creek project is a 1.5-MW hydroelectric installation located about 10 miles east of Hydaburg, Alaska. Phase I will generate 11,500 MWh/yr and displace about 480,000 gallons/yr of diesel fuel.

Sitka Project. The city of Sitka's new diesel generator installation replaces generation from a decommissioned diesel-fired power plant. The new equipment will have a capacity of 4.5 MW. Construction was completed in September 2002.

Sheldon Jackson College (a.k.a. Indian River) Projects. These projects are funded through the Sitka Project and are located on the campus of Sheldon Jackson College in Sitka, Alaska. One part of the project is to rehabilitate and restart a $104 \mathrm{~kW}$ hydropower plant (28.5-foot design head) to generate and distribute low-cost electricity for the college steam plant. The electrical distribution system will also be upgraded.

Swan Lake - Lake Tyee Intertie. Ketchikan Public Utilities is constructing this transmission line to connect the Swan Lake and Lake Tyee hydropower projects with the cities of Petersburg, Wrangell, and Ketchikan, Alaska. The $138 \mathrm{kV}$ intertie will be 57 miles long and have a capacity of $25 \mathrm{MW}$. Distribution of electricity from the Lake Tyee hydro project is presently constrained. The new line will allow full distribution of the $134,400 \mathrm{MWh}$ annual electrical output from the Lake Tyee project. The new access to hydropower generation will serve the needs of the three communities through the year 2015.

Falls Creek Project. Gustavus Electric Company's planned hydropower project is located about five miles east of Gustavus, Alaska. The project includes an 800-kW impulse turbine and generator unit operating on a 500-foot design head and generating about $4,800 \mathrm{MWh} / \mathrm{yr}$. This project will eventually displace 425,000 gallons of diesel fuel per year.

Prince of Wales Intertie. The Alaska Energy Authority is managing the two phases of the Prince of Wales Intertie project. Project phases include: (1) the construction (by Alaska Power \& Telephone) of 35 miles of $34.5 \mathrm{kV}$ transmission line (connecting Thorne Bay and Kassan, Alaska with the Bear Lake hydro system), and (2) the upgrade and installation (by Alaska Power Co.) of 41.3 miles of transmission line (connecting Hydaburg and Hollis with the Craig-Kassan system), the construction of two substations (near Hydaburg), and the installation of a 1,135 kW diesel generating plant (in Craig).

Glennallen Power Upgrade Project. Copper Valley Electric Association's Glennallen project includes: (1) expanding the existing Glennallen power plant by adding a 3,900 kW diesel generator, and (2) constructing a 19-mile, $25 \mathrm{kV}$ transmission line connecting Lake Louise with the Glennallen electric system. 
Table A-1. Summary of Alaska projects administered by the U.S. Department of Energy.

\begin{tabular}{|c|c|c|c|c|c|}
\hline $\begin{array}{l}\text { Project } \\
\text { Name }\end{array}$ & $\begin{array}{c}\text { Project } \\
\text { Description }\end{array}$ & $\begin{array}{l}\text { Start } \\
\text { Date }\end{array}$ & $\begin{array}{c}\text { Complete } \\
\text { Date }\end{array}$ & $\begin{array}{l}\text { Project } \\
\text { Cost }\end{array}$ & $\begin{array}{l}\text { Project } \\
\text { Status }\end{array}$ \\
\hline $\begin{array}{l}\text { Power } \\
\text { Creek } \\
\text { (CEC) }\end{array}$ & $6 \mathrm{MW}$ Hydro & $4 / 92$ & $12 / 01$ & $\$ 23,800,000$ & Construction complete \\
\hline $\begin{array}{l}\text { Sitka } \\
\text { (City of } \\
\text { Sitka) }\end{array}$ & 4.5 MW Diesel & $7 / 97$ & $9 / 02$ & $\$ 4,660,500$ & Construction complete \\
\hline SJC & $\begin{array}{l}104 \text { kW Hydro } \\
\text { Rehabilitation }\end{array}$ & $5 / 01$ & $10 / 03$ & $\$ \quad 198,000$ & $\begin{array}{c}\text { Rehabilitation contingent upon } \\
\text { non-jurisdictional finding by } \\
\text { FERC; Awaiting final FERC } \\
\text { Order }\end{array}$ \\
\hline SJC & $\begin{array}{l}\text { Electric } \\
\text { System } \\
\text { Upgrade }\end{array}$ & $5 / 01$ & $10 / 03$ & $\$ 1,134,000$ & $\begin{array}{c}\text { Construction bid documents } \\
\text { issued } 8 / 02\end{array}$ \\
\hline $\begin{array}{l}\text { Reynolds } \\
\text { Creek } \\
\text { (Haida) } \\
\end{array}$ & $\begin{array}{l}\text { 1.5 MW Hydro } \\
\text { (Phase I) }\end{array}$ & $5 / 88$ & $12 / 04$ & $\$ 7,800,000$ & $\begin{array}{l}\text { FERC License issued } 10 / 00 ; \\
\text { Date to begin construction } \\
\text { extended to } 10 / 04 \text { by FERC }\end{array}$ \\
\hline $\begin{array}{l}\text { Pyramid } \\
\text { Creek } \\
\text { (UEU) }\end{array}$ & 600 kW Hydro & $9 / 97$ & $9 / 04$ & $\$ 3,212,000$ & $\begin{array}{c}\text { Determination made that an EA } \\
\text { is required }\end{array}$ \\
\hline $\begin{array}{l}\text { Old Harbor } \\
\text { (AVEC) }\end{array}$ & 500 kW Hydro & $1 / 95$ & & $\$ 2,745,000$ & $\begin{array}{l}\text { FERC License issued } 12 / 00 ; \\
\text { Date to begin construction } \\
\text { extended to } 12 / 04 \text { by FERC }\end{array}$ \\
\hline $\begin{array}{l}\text { Scammon } \\
\text { Bay } \\
\text { (AVEC) }\end{array}$ & $\begin{array}{l}100 \text { kW Hydro } \\
\text { Feasibility } \\
\text { Study }\end{array}$ & $3 / 99$ & $1 / 02$ & $\$ \quad 100,000$ & $\begin{array}{c}\text { Feasibility Study determined } \\
\text { the project to be uneconomical; } \\
\text { Balance of funds to Old Harbor } \\
\text { project }\end{array}$ \\
\hline $\begin{array}{l}\text { Nome } \\
\text { (NJUS) }\end{array}$ & $\begin{array}{l}4.5 \mathrm{MW} \\
\text { Diesel }\end{array}$ & $9 / 00$ & $12 / 04$ & $\$ 3,455,000$ & $\begin{array}{l}\text { Project site to be relocated; } \\
\text { Redesign underway due to } \\
\text { engineering design review and } \\
\text { feasibility reassessment }\end{array}$ \\
\hline $\begin{array}{l}\text { Swan Lake } \\
\text { - Lake } \\
\text { Tyee } \\
\text { (KPU) }\end{array}$ & $\begin{array}{l}\text { 57-mile, } 138 \\
\text { kV Trans. Line }\end{array}$ & $5 / 94$ & $12 / 04$ & $\$ 76,500,000$ & $\begin{array}{l}\text { Final design underway; Initial } \\
\text { clearing of ROW started }\end{array}$ \\
\hline $\begin{array}{l}\text { Falls Creek } \\
\text { (GEC) }\end{array}$ & 800 kW Hydro & $6 / 99$ & $6 / 06$ & $\$ 5,765,000$ & $\begin{array}{c}\text { FERC License application filed } \\
\text { 10/01; License expected } 3 / 4\end{array}$ \\
\hline
\end{tabular}




\begin{tabular}{|c|c|c|c|c|c|}
\hline $\begin{array}{l}\text { Project } \\
\text { Name }\end{array}$ & $\begin{array}{c}\text { Project } \\
\text { Description }\end{array}$ & $\begin{array}{l}\text { Start } \\
\text { Date }\end{array}$ & $\begin{array}{c}\text { Complete } \\
\text { Date }\end{array}$ & $\begin{array}{l}\text { Project } \\
\text { Cost }\end{array}$ & $\begin{array}{l}\text { Project } \\
\text { Status }\end{array}$ \\
\hline $\begin{array}{l}\text { Prince of } \\
\text { Wales } \\
\text { (AEA) }\end{array}$ & $\begin{array}{c}\text { Electric } \\
\text { System } \\
\text { Improvements: } \\
\text { 35-mile, 34.5 } \\
\text { kV Trans. Line } \\
\text { (Phase 1) } \\
\text { 41.3-mile } \\
\text { intertie } \\
\text { upgrades, new } \\
\text { substations, } \\
\text { 1,135 kW } \\
\text { Diesel } \\
\text { Generation } \\
\text { Plant } \\
\text { (Phase 2) }\end{array}$ & $9 / 97$ & $12 / 04$ & $\begin{array}{c}\$ 8,170,000 \\
\text { (Phase 1) } \\
\$ \\
11,170,000 \\
\text { (Phase 2) } \\
\begin{array}{c}\$ 19,340,000 \\
\text { (Total) }\end{array}\end{array}$ & $\begin{array}{c}\text { Phase } 1 \text { complete; Phase } 2 \\
\text { under construction }\end{array}$ \\
\hline $\begin{array}{l}\text { Glennallen } \\
\text { (CVEA) }\end{array}$ & $\begin{array}{l}\text { 3.9 MW Diesel } \\
\text { Addition @ } \\
\text { Glennallen } \\
\text { Plant; } \\
\text { 19-mile, } 25 \text { kV } \\
\text { Trans. Line } \\
\text { extension to } \\
\text { Lake Louise }\end{array}$ & $7 / 02$ & $7 / 04$ & $\begin{array}{c}\text { Diesel } \\
\text { Addition } \\
\$ 3,780,000 \\
\text { Trans. Line } \\
\$ 2,720,000 \\
\text { Total } \\
\$ 6,500,000\end{array}$ & \\
\hline
\end{tabular}

CEC - Cordova Electric Cooperative (Cordova, AK)

SJC - Sheldon Jackson College (Sitka, AK)

Haida - Haida Corporation (Native American - Hydaburg, AK)

UEU - Unalaska Electric Utilities (Unalaska, AK)

AVEC - Alaska Village Electric Cooperative, Inc. (Anchorage, AK)

NJUS - Nome Joint Utility System (Nome, AK)

KPU - Ketchikan Public Utilties (Ketchikan, AK)

GEC - Gustavus Electric Co. (Gustavus, AK)

AEA - Alaska Energy authority (Anchorage, AK)

CVEA - Copper Valley Electric association, Inc. (Glennallen, AK) 



\section{A Strong Energy Portfolio for a Strong America}

Energy efficiency and clean, renewable energy will mean a stronger economy, a cleaner environment, and greater energy independence for America. By investing in technology breakthroughs today, our nation can look forward to a more resilient economy and secure future.

Far-reaching technology changes will be essential to America's energy future. Working with a wide array of state, community, industry, and university partners, the U.S. Department of Energy's Office of Energy Efficiency and Renewable Energy invests in a portfolio of energy technologies that will:

- Conserve energy in the residential, commercial, industrial, government, and transportation sectors

- Increase and diversify energy supply, with a focus on renewable domestic sources

- Upgrade our national energy infrastructure

- Facilitate the emergence of hydrogen technologies as vital new "energy carriers."

\section{The Opportunities}

Biomass Program

Using domestic, plant-derived resources to meet our fuel, power, and chemical needs

\section{Building Technologies Program}

Homes, schools, and businesses that use less energy, cost less to operate, and ultimately, generate as much power as they use

Distributed Energy \& Electric Reliability Program

A more reliable energy infrastructure and reduced need for new power plants

Federal Energy Management Program

Leading by example, saving energy and taxpayer dollars in federal facilities

FreedomCAR \& Vehicle Technologies Program

Less dependence on foreign oil, and eventual transition to an emissions-free, petroleum-free vehicle

Geothermal Technologies Program

Tapping the Earth's energy to meet our heat and power needs

Hydrogen, Fuel Cells \& Infrastructure Technologies Program

Paving the way toward a hydrogen economy and net-zero carbon energy future Industrial Technologies Program

Boosting the productivity and competitiveness of U.S. industry through improvements in energy and environmental performance

Solar Energy Technology Program

Utilizing the sun's natural energy to generate electricity and provide water and space heating

Weatherization \& Intergovernmental Program

Accelerating the use of today's best energy-efficient and renewable technologies in homes, communities, and businesses

Wind \& Hydropower Technologies Program

Harnessing America's abundant natural resources for clean power generation

To learn more, visit www.eere.energy.gov 
